\title{
1914 Yılında Yayınlanan Kadın Gazetelerinden ‘Kadınlık'a Göre Kadın
}

\author{
Yrd. Doç. Dr. Besim YILDIRIM \\ Doç. Dr. Salih SEYHAN
}

atatürk üniversitesi iletişim fakültesi gazetecilik bölümü besim@atauni.edu.tr salihseyhan34@gmail.com

\begin{abstract}
Woman According to 'Kadınlık', a Women Newspaper Published in 1914

This study aims to understand the role of the women in the modernization period of the Ottoman Empire by exploring the media content of that period. 11 original copies of the Kadınlık (Womanhood) newspaper are taken into consideration as an example of the study from the March 8th to May 17th 1330 published in Ottoman Turkish with Arabic alphabet. After having presented general information about the newspaper, we tried to analyze the articles of Ebussureyya Sami, Halis Esref, Sukufe Nihal Mithat, Mahmud Sadık, Nevvera Sukran and HaCl Cemal, writers who had written a lot about the status of Ottoman women. The articles have been analyzed by qualitative content analysis in order to be able to reveal the newspaper's attitude related to the women's status. As a result, despite the existence of different points of view of the writers, we observed that different aspects of the women's identity and status, i.e. family life, education, marriage and divorce law, working conditions, have been discussed within the context of historical, political and social conditions of the period.
\end{abstract}

keywords: Kadınlık, women in the Ottoman Empire, women's magazines, women newspapers 


\section{Résumé}

\section{4 \\ La femme selon 'Kadınlık', l'un des journaux des femmes, publié en}

Nous envisageons par cette recherche de comprendre le rôle attribué aux femmes au cours de la période de modernisation dans l'Empire ottoman et de révéler les sujets liés aux femmes publiés à l'époque à partir de l'exemple du journal Kadınlık. Pour ce faire, nous avons analysé onze numéros du journal, publiés entre 8 mars 1330 et 17 mai 1330, en ottoman avec l'alphabet arabe, en les transformant au format digital. La recherche présente dans un premier temps les informations générales et techniques à propos du journal. Ensuite, le contenu des articles de certains écrivains qui ont plutôt traité des sujets portant sur le statut social de la femme, comme Ebussüreyya Sami, Halis Eşref, Şukufe Nihal Mithat, Mahmud Sadık, Nevvera Sü̈kran et Hacı Cemal, furent analysés qualitativement, ce qui rend le travail une monographie. Selon les analyses, nous pouvons indiquer que même s'il y a des points de vue différents au sein des écrivains du journal à propos de l'identité et le statut social des femmes, il est tout de même possible d'observer que, dans le contexte historique, politique et social de l'époque, les sujets les plus traités furent les suivants: le statut de la femme dans la famille, son éducation, les lois sur le mariage et la divorce, les conditions selon et dans lesquelles les femmes peuvent travailler.

mots-clés: Kadınlık, la femme à l'époque ottomane, les magazines des femmes, les journaux des femmes

\section{Özet}

Osmanlı modernleșme sürecinde kadınlara biçilen rolü anlamak ve o dönemde basının gündeminde yer almış olan kadına ilişkin konuları Kadınlık Gazetesi bağlamında ortaya çıkarmayı amaçlayan bu çalışmada, gazetenin 8 Mart 1330-17 Mayıs 1330 tarihleri arasındaki orijinal Arap harfli Osmanlıca 11 nüshası, dijital ortama aktarılarak incelenmiştir. Araştırmada öncelikle kimlik bilgileri ve teknik özellikleri gibi gazeteye ait genel bilgiler sunulmuştur. Daha sonra gazetenin kadına biçtiği role ilişkin yaklaşımlar üzerinde yorum yapabilmek ve derginin kadının konumuna ilişkin tutumunu ortaya koymak amacıyla, yazılarında kadının toplumsal konumuyla ilgili meselelere yoğunlaşan Ebussüreyya Sami, Halis Eşref, SSukufe Nihal Mithat, Mahmud Sadık, Nevvera Şükran ve Hacı Cemal'e ait yazılar niteliksel içerik analizi yöntemiyle incelenmiştir. Çalışma bu yönüyle monografi özelliği taşımaktadır. Değerlendirmeler sonucunda gazetenin yazarları arasında kadının kimliği ve konumuna ilişkin farkı bakış açılarının varlığı dikkat çekse de, ağırlıklı olarak, dönemin tarihsel, siyasal ve toplumsal koşulları bağlamında, kadının aile içindeki konumu, eğitimi, evlilik boşanma hukuku, kadının nasıl ve hangi hallerde çalışması gerektiğine yönelik konuların gündeme getirildiği anlaşılmıştır.

anahtar kelimeler: Kadınık, Osmanlı'da kadın, kadın dergileri, kadın gazeteleri 


\section{Giriş}

II. Meşrutiyet'in hemen ardından yayınlanan gazete ve dergilerin hemen hepsi, II. Abdülhamit'in dönemine, "Zulüm ve istibdattan, kahır ve baskıdan ibaret olan eski idareyi", (Nadir, 1908: 1), "... zalam ve enin dolu günlerde, memleketin esaret ve istibdat altında inim inim inlediği günlerde..." (Şayan-ı Teessüf Bir Mülakat, 1908: 1) gibi cümlelerle göndermelerde bulunmuşlardır. Kadınlık Gazetesi de II. Meşrutiyetin ilanından çok sonra (1914) yayınlanmış olmasına rağmen, II. Meşrutiyet'in ilanından sonra geçen dönemi de içine alarak eski devirleri, "Şimdiye kadar cehlin kara pençeleriyle yırtılan gariban-ı nisviyete ilmi, edebi ve ailevi çiçekler, güller takmak ve mübareze-i hayatiyeye iştirak için o zayıf dimağları silah-ı ilm ve irfan ile teçhiz eylemek içün çalışacaktır" ifadeleriyle yermiştir ("Mesleğimiz", Kadınlık, 8 Mart 1330, Numru 1, s.2).

II. Abdülhamid'in bu şekilde tanıtılması gelişmekte olan İttihat Terakki Cemiyeti'nin de teşkilatlanmasını kolaylaştırmış, devletin her köşesinde kendisine taraftar bulabilmiştir. Cemiyet'in fikirlerini her tarafa yaymak için en önemli araçlardan biri ise basın olmuştur. İttihat Terakki'ye ait yayın organlarından, Cemiyet'in kendileri ile ilgili olumlu görüşlerini okuyup, sıkı bir Cemiyet taraftarı olan kadınların sayısı da Selanik başta olmak üzere ülkenin her yerinde fazlalaşmıştır.

II. Meşrutiyet, Osmanlı açısından sosyal, siyasal, eğitim, hukuk gibi toplumsal alanlarda dönüşüm ve değişime gidildiği bir dönemdir. Osmanlı modernleşmesinde öncülük edecek yapısal değişimler bu dönemde ivme kazanmış, siyasal yapıda farklılaşma, laikleşme, özgürleşme sürecine girilmiştir. Yine bu dönemde toplumsal geri kalmışlıkla kadının eğitimi arasında paralellik kurulmuş, batıyı yakalamak için kadınların eğitilmesi gerektiği konusu sıklıkla vurgulanmıştır. Bu değişim ve dönüşüm içerisinde kadınlara geleneksellik ile modernlik arasında dengeyi kurma rolü biçilmiş, bu çerçevede kadınlara yönelik birçok dergi ve gazete yayınlanmıştır. Bu yayınlarla kadın erkek ilişkilerinin, geleneksel biçimleri eleştirilmeye başlanmış, kadının toplumsal statüsünün yeniden inşası için mücadele verilmiştir.

Zaman içerisinde kadınların aktif katılımlarıyla zenginleşip, etkin hale gelen bu gazete ve mecmualar toplumun kurtuluşunun ancak kadının yükselişiyle mümkün olabileceği görüşünden hareketle, Osmanlı'daki kadın sorununa farklı açılardan yaklaşımasına olanak sağlamış ve kadının toplumsal konumunun iyileştirilmesinde başlangıç noktası oluşturmuşlardır. Bu haliyle II. Meşrutiyet dönemi, kadınlar için bir aydınlanma döneminin de başlangıcıdır denilebilir (Çakır 1994: 22). Ayrıca bu dönem gazete ve dergileri, mahrem görülen ve olabildiğince sınırlanan kadın yaşam alanlarının giderek toplumsallık ve görünürlük kazanmasında önemli bir rol oynamışlardır (Göle 2000: 24). 
Öte yandan bu dönem sadece kadınlarla ilgili özgürlükçü düşüncelerin ifade edildiği, kısmen de olsa uygulandığı bir dönem olmamıştır. Kadının giderek daha fazla kamusal alanda görünür olmasının yanı sıra, buna karşı gelişen tepkilerin de dile getirildiği bir süreç olmuştur. Bu karşıt görüşlerin ise kadının iyi bir anne, iyi bir eş ve iyi bir Müslüman olmasına katkıda bulunmak şeklinde son derece basit ve sınılı bir amaç taşıdığı söylenebilir. Dönemin aydınları, kadın konusunu benimsedikleri fikir akımları bağlamında gündeme getirmiş ve bu doğrultuda kadının toplumsal konumunun nası olması gerektiğine ilişkin fikirler beyan etmişlerdir. Öyle ki bu süreçte kadının toplumsal konumuna ilişkin tartışmalar "ilerici-gerici" ikileminde çerçevelenmiştir."

Osmanlıdan Cumhuriyet'e kadar yayınlanan birçok kadın dergi ve gazetelerinin incelenmesi dönem içerisinde kadının toplumsal konumu ve kadınlara biçilen rolü kavramak açısından önemli olduğu kadar, dönemin feminist söylemini anlamak açısından da değerlidir. Bu bağlamda gerek iletişim, gerek tarih ve gerekse edebiyat çalışmaları çerçevesinde birçok araştırma yapıımıştır. Ancak özellikle Osmanlı dönemindeki yayınların incelenmesi, çeviri ve arşiv sorunu nedeniyle güçlükle yürütülmekte ve bu durum alandaki çalışmaların niceliğini olumsuz yönde etkilemektedir. Bu alandaki çalışmalar öncelikle kadınlara yönelik çıkarılan yayınlarla ilgili bibliyografik incelemelerle2 başlamış, bu çalışmalar kadının toplumsal konumuna, dönemin kadın söylemine ilişkin yapılan topyekün değerlendirmeler ${ }^{3}$ ya da müstakil dergi ve gazeteler bağlamında yapılan spesifik

1 Bu araştırmanın konusu ve sınırlıı̆ı açısından çalışmada bu tartışmalara yer verilmemiştir. Ancak söz konusu tartışmalarla ilgili detaylı bilgi için şu kaynaklara bakılabilir: Nilüfer Göle. (2000). Modern Mahrem, İstanbul: Metis Yayınevi. / Aksu Bora ve Deniz Kondiyoti (2000). Cariyeler, Bacılar, Yurttaşlar, İstanbul: Metis Yayınevi. / A. Nilüfer Durakbaşa (1998). "Cumhuriyet Döneminde Modern Kadın ve Erkek Kimliklerinin Oluşumu: Kemalist Kadın Kimliği ve 'Münevver Erkekler'", içinde 75 Yılda Kadınlar ve Erkekler, (Der) A. Berktay Hacımirzaoğlu, Ankara: Tarih Vakfı Yayınları. / Mithat Kutlar (2008). Ulviye Mevlan: Yaşamı ve Düşünceleri. Yayınlanmamış Yüksek lisans Tezi, Ankara Üniversitesi Sosyal Bilimler Enstitüsü. / Serpil Sancar (2004). "Otoriter Türk Modernleşmesinin Cinsiyet Rejimi", Doğu Batı, İdeolojiler II, Sayı 29. ss. 197-211.

2 Bu çalışmaların başlıcaları şunlardır: Emel Aşa (1992). "1869-1923 Yıları Arasında Yayımlanan Türk Kadın ve Aile Dergileri", Sosyo Kültürel Değişme Sürecinde Türk Ailesi, C. 3, Ankara, ss. 966-978. / Zehra Toska vd. (1993). Istanbul Kütüphanelerindeki Eski Harfli Türkçe Kadın Dergileri Bibliyografyası (1869-1927), Kadın Eserleri Kütüphanesi ve Bilgi Merkezi Vakfı Yayını: 5, İstanbul: Metis Yayını.

3 Bu çalışmaların bazıları için bakınız: Safiye Akdeniz (2008). "Tanzimat Dönemi Edebiyatçılarının Kadın Problemine Yaklaşım Biçimleri", Ege Üniversitesi Türk Dili ve Edebiyatı Araştırmaları Dergisi, Sayı:15, ss. 1-32. / Serpil Çakır (1994). Osmanlı Kadın Hareketi, İstanbul: Metis Yayınları. / Şefika Kurnaz (1991). Cumhuriyet Öncesinde Türk Kadını (1839-1923), Ankara: T.C. Başbakanlık Aile Araştırma Kurumu Başkanlığı Yayınları / Ahmet Özkiraz ve Nazan Aslanel (2011). “ikinci Meşrutiyet Döneminde Kadın Olmak", Sosyal ve Beşeri Bilimler Dergisi, Cilt:3, No:1, ss. 1-10. ISSN. / Hüseyin Akyol (2012). Aykırı Kadınlar (Osmanlı'dan Günümüze Devrimci Kadın Portreleri), Ankara: Imge Kitabevi / Leyla Kaplan (1999), "II. Meşrutiyet Dönemi Osmanlı Kadınlarının Özgürleşme Hareketi", Osmanlı Ansiklopedisi, Cilt 5, Yeni Türkiye Yayınları, Ankara, ss. 446-473. / Serpil Çakır (1992), "II. Meşrutiyet Devri Kadınlarının Aile Anlayışları", Sosyo Kültürel Değişme Sürecinde Türk Ailesi, C. 1, Ankara, ss. 238-251. / Nilüfer Özcan Demir (1999). II. Meşrutiyet Dönemi Osmanlı Feminizmi, Hacettepe Üniversitesi Edebiyat Fakültesi Dergisi, Cilt 16, Sayı 2, ss. 107-116. / Aksu Bora ve Deniz Kondiyoti (2000). Cariyeler, Bacılar, Yurttaşlar, İstanbul: Metis Yayınevi. 
çalışmalar4 için önemli bir altyapı oluşturmuştur.

Bu çalışma, II. Meşrutiyet'ten sonra kadınlara yönelik yayınlardan biri olan Kadınlık Gazetesi'ni konu edinmektedir. Araştırmanın amacı ise Osmanlı modernleşme sürecinde kadınlara biçilen rolü anlamak ve o dönemde basının gündeminde yer almış olan kadına ilişkin konuları Kadınlık Gazetesi bağlamında ortaya çıkarmaktır.

Türk modernleşme sürecinde kadınların hak ve özgürlük mücadelesindeki kazanımlarında etkin rol oynayan bu tür yayınlar kadın hareketinin gelişimi açısından önemlidir ve dönemin kadın söyleminin anlaşılması için bu yayınların araştırılması gereklidir. Kadınların eğitimi, toplumsal konumu ve örgütlenmesi ile ilgili oluşturduğu söylem açısından Meşrutiyet dönemi kadın yayınları içerisinde önemli bir yeri olan ve Osmanlı kadın hareketinde rol alan kadın aydınların yazılarının da yer aldığı Kadınlık Gazetesi, dönemin kadın hareketlerinin anlaşılması açısından önemli bir kaynaktır. Ancak, dergi hakkında bilinenler, bibliyografik çalışmalara ve alanla ilgili diğer incelemelerde yer alan kısa bilgilere dayanmaktadır. Kadınlık Gazetesi hakkında ayrıntılı bilgiler içeren ve özgün bir karakter taşıyan bu çalışma, Kadınlık Gazetesi'nin kadına biçtiği rolü ve oluşturduğu kadın söylemini dönemin tarihsel ve toplumsal koşulları bağlamında anlamaya çalışmasının yanı sıra, kadına yönelik yayıncılığın incelenerek kadın yazınına katkı sağlaması, benzer araştırmaların önemi vurgulanarak, konuya ilişkin yeni çalışmalara alt yapı oluşturması açısından da önemlidir. Çalışmada Kadınlık Gazetesi hangi amaçla çıktığı, biçimsel ve içeriksel özellikleri ve kadınların toplumsal konumuna ilişkin yaklaşımı çerçevesinde ele alınmıştır.

\section{Tanzimat Dönemi Kadın Dergi ve Gazeteleri}

Jön Türk hareketinin temelleri Tanzimat dönemindeki Yeni Osmanlılar Cemiyeti tarafından atılmış ve bu cemiyet tarafından Batı'da gerçekleşen ilerlemelerde kadının rolü yakından takip edilmiştir. Dolayısıyla bu dönemde de kadın meselesi, aydınların gündeminden düşmemiştir. Mesela Namık Kemal Ibret gazetesindeki bir yazısında genç kadınların çağdaş toplumlardaki rollerine dikkat çekerek şu ifadeleri kullanmıştır:

\footnotetext{
"Biliyoruz ki memalik-i mütemeddinede kadınları da erkekler gibi terbiye ederler. Fakat şurasını dahi anlamalı ki o kadınlar içinde kendi lisanının ve kendi devletinin birincisi sayılacak derecede katibeler, şaireler zuhur ediyor. On sekiz yaşında bir kız çıkıyor, hikemiyattan hesab-i tefazuli gibi dakik dersler okutuyor.
}

4 Bu çalışmalara örnek olarak şunlar gösterilebilir: Fatma Kılıç Denman (2009). ikinci Meşrutiyet Döneminde Bir Jön Türk Dergisi: Kadın, İstanbul: Libra Kitapçılık ve Yayınclık. / Tülay Keskin (2005). "Demet Dergisi'nde Kadın ve İlerleme Anlayışı", Tarih Araştırmaları Dergisi, Cilt: 24 Sayı: 37, ss. 289-312. / Fatma Tunç Yaşar (2008). "Osmanlı Kadınının Eğitimine Yönelik Illk Süreli Yayın: Terakki-i Muhadderat", Değerler Eğitimi Merkezi Dergisi (3), ss. 98-105. / Erdinç Gülcü ve Samiye Tunç (2012). Osmanlı Basın Hayatında Kadınlar Dünyası Dergisi, Çankırı Karatekin Üniversitesi Sosyal Bilimler Enstitüsü Dergisi 3(2), ss. 155-176. 
Karşısında aksakallı hocalar kitap tutarak istifadeye çalışıyor. Memleket bulunur ki her nevi mekteplerinde olan hocaların nısfından ziyadesi kadınlar veya daha vazıh tabir olunmak istenilirse yirmibeş, yaşına varmamış, kızlardır. Cumhur reisleri, nazırlar, vükela-yı ümmet, generaller, memurlar, alimler, edipler hemen ekseriyet itibariyle zevcelerini onlardan intihap ederler" (Özön 1997: 97).

Yeni Osmanlılar Cemiyeti'nin yayın organları arasında sayılan Tanzimat döneminin ilk özel gazetelerinde, kadınların eğitimine çok önem verilmiş, yukarıda ifadeleri verilen Namık Kemal dışında, Ahmet Mithat Efendi ve Şemseddin Sami gibi erkek yazarlar da ${ }^{5}$ kadın konusunda müstakil eserler ortaya koymuşlardır.

Tezer Taşkıran, kadın hakları ile ilgili ilk düzenlemelerin de bu dönemde olduğunu belirterek şöyle demektedir: "Tanzimat dönemi reformlarının belki de en önemlisi; kadınların kısıtı da olsa eğitimle ilgili yapılan reformlar sonucunda, toplum hayatına katılmaya başlamasıdır. Bu dönemde kadınlar lehine kanunlarda değişiklikler yapılmış, yasaklar nispeten yumuşatılmış, ayrıca fikir ve edebiyat alanında kadınların haklarını savunan yazılar yazıımaya başlanmıştır." (Taşkıran 1973'den aktaran Özkiraz ve Aslanel 2011:2)

Sultan II. Abdülhamid döneminin tamamını bir aydın olarak yaşayan ve gözlemleyen Fatma Aliye Hanım (1862-1936), hem Tanzimat hem de II. Meşrutiyet Döneminin en önemli kadın yazarı olmakla kalmayıp dönemin hemen hemen bütün kadın yazarlarını etkilemiş ve kadınların sosyal hayatın içinde yer almasını savunarak onlara öncülük yapmıştır. Fatma Aliye, toplumun diğer yarısını oluşturan kadının çalışmasının, refah seviyesini artıracağını, ancak kadının toplumsal hayattan dışlanmasıyla Osmanlı Devleti'nin ilerlemesinin yavaşladığını dile getirir. Kadının toplumsal hayattan dışlanarak, niteliksiz işlerde düşük ücretlerle çalışmasının da geçimini sağlamasına yetmeyeceğini ifade eder:

"Nihayet kadına bir çamaşırcılık bir de dikişçilik hizmetinden başka bir şey bırakılmamış idi. Çamaşırcılıktan alacağı beş on kuruş ve üç dört gün sarfıyla dikebileceği bir pamuklu hırka veya bir entariden alacağı beş kuruşla temin-i maişet mümkün değil" (Karaca 2011a: 106).

Öte yandan Fatma Aliye'nin kız kardeşi olan Emine Semiye de kadın konusundaki düşünceleriyle öne çıkan yazarlar arasındadır. Her iki kardeş te kadına dair konulara duyarlı olmalarına rağmen, zaman zaman fikir ayrılıkları yaşamışlardır. Emine Semiye ablası Fatma Aliye'ye göre kadın konusunda kalıplaşmış toplumsal bakış açısının dışında bir görüşe sahiptir6. Ona göre kadın,

5 Ancak o dönem erkeklerin kadınlar için verdiği destek, ataerkil toplumsal cinsiyet bağlamında daha çok iyi bir eş veya annelik rollerini daha nitelikli yapabilmeleri noktasında olmuş, çok daha sonraları, 1980'lerden itibaren daha feminist bir perspektife doğru evirilebilmiştir.

6 Emine Semiye'nin kardeşine göre kadın konusundaki farklı, daha batıcı düşüncelere sahip olması onun uzun yıllar boyunca yurtdışında eğitim almasından kaynaklanıyor olabilir. Zira Batı'da eğitim gören ilk Türk kadınlarından biri olan Emine Semiye Fransa ve İsviçre'de 7 yıl psikoloji ve sosyoloji eğitimi almıştır. 
eğitiminden eş seçimine ve çalışma yaşamına ilişkin birçok konuda özgürce seçim yapabilecek kadar güçlü olmalıdır. Fatma Alıye'de ise kadın, ekonomik özgürlüğe kavuşturulsa bile, yine de bu özgürlük geleneksel sınırlar içinde kalmıştır (Karaca 2013: 1482). Her iki yazar da kadın eğitimine büyük önem vermiştir. Ancak Fatma Aliye'de eğitim kadını iyi bir anne ve eş olarak topluma eklemleyen bir işlev görürken; Emine Semiye'de kadının ataerkil yapıdaki pasifize edilmiş kimliğini etken hale dönüştürecek bir farkındalığa ulaştıran ve bağımsız bir kadın kimliğinin kurulmasına yardım eden bir fonksiyondadır. Bu bağlamda siyasetçi, kadın hakları savunucusu, eğitimci kimliğiyle Emine Semiye Osmanlı'daki feminist hareketlerinin öncüleri arasında yer almıştır (Karaca 2011b: 130-131).

Osmanlı döneminde kadın haklarından bahseden ilk gazete, 1868 yılında çıkmaya başlayan Terakki'dir7. Gazete, batılı kadınların haklarına, eğitimlerine verdikleri önem sayesinde kavuştuklarına dikkat çekerek, kadınların eğitimi konusuna, kadın okuyucularından gelen mektuplara, önemli bir yer ayırmıştır. Kadınlara yönelik ilk süreli yayın olarak kabul edilen ve her hafta Pazar günleri yayımlanan gazete daha sonra iffetli kadın anlamında kullanılan Muhadderat adlı bir ek de çıkarmıştır (Kurnaz 1991: 39). Iffetli kadınların ilerlemesi, gelişmesi ya da Müslüman kadınların ilerlemesi anlamına gelen Terakki-i Muhadderat'da kadınlar, derginin editörü ve tek yazarı Ali Raşit kalemiyle dile getirilmiş, okuyucu mektupları dışında kadın sesi yer almamıştır (Yaşar 2008: 99). Tanzimat anlayışının tipik bir ürünü olan Terakki-i Muhadderat, kadını, iyi bir eş ve anne rolü bağlamında kamusal alanın uzağında, ev merkezli olarak tanımlamış ve bu çerçevede kadına yönelik bakış açısı geleneksel ve muhafazakâr bakış açısıyla sınırlı kalmıştır (Çağlıyan 2002: 135).

II. Meşrutiyet'in ilanına kadar çıkarılan kadın gazete ve mecmualardan öne çıkanlar şu şekilde sıralanabilir: Ayine 1291-93 (1874-1876), Vakit Yahut Mürebbi-i Muhadderat 1292 (1875), Aile 1297 (1880), Insaniyet 1300 (1882-83), Hanımlar 1300 (1882-83, Şükufezar 1301 (1883-84), Mürüvvet 1303 (1885-86), Parça Bohçası 1305 (1887-88), Hanımlara Mahsus Gazete 1311-1324 (18931907), Hanımlara Mahsus Malumat 1312-1313 (1894-1896), Takvim-i Nisa 1317 (1899-1900) (Kurnaz 1991: 43; Aşa 1992; Çakır 1996: 22-42).

Bu dergi ve gazetelerden sadece Ayine Selanik'te, diğerlerinin tamamı İstanbul'da yayınlanmıştır. Bu dönemdeki yayınların temel gayesi, kadınların eğitimi meselesidir. Yazılarının tamamı kadınlar tarafından yayınlanan bu süreli yayınların en uzun ömürlüsü, aralıklarla 15 yıl devam eden Hanımlara Mahsus Gazete'dir (Kurnaz 1991: 43). Bu gazete ve dergilerde toplumun geri kalmışlığıyla kadınlar arasında bir paralellik kurulmuştur. Bu bağlamda batının etkisiyle gelişen sosyal ve edebi hayat sonucunda kadınların eğitilmesi gerçekleşmedikçe ilerlemenin kaydedilmesi mümkün olamayacağı fikri yerleşmiş ve Osmanlı

7 Ali Raşid ve Filip Efendi'nin 1868'de kadınlara yönelik çıkarttıkları gazete haftalıktır ve ayrıca haftalık mizah nüshası da bulunmaktadır (Kurnaz, 1991: 39). 
Aydınları bu konuda ciddi bir gayretin içine girmişlerdir. Bu dönemin kadınlara yönelik yayınların içeriklerini genel itibariyle evlilik, ev ekonomisi, kadınların eğitilmesi, kadınların aile içindeki rolleri, çokeşlilik, boşanma, örtünme ve esaret gibi konular oluşturmaktadır (Akdeniz 2008: 3). Sonuç olarak gazete ve mecmualarda kadının kalıplaşmış cinsiyet rolleri çerçevesinde, iyi bir anne ve eş olabilmesi, bir sonraki nesli yetiştirebilmesi ve böylece toplumsal gelişime katkıda bulunmaları için eğitilmesi gerektiği vurgusu yapılmıştır.

\section{II. Meşrutiyet Dönemi Kadın Dergi ve Gazeteleri}

Osmanlı toplumunda kadının konumunun yükseltilmesi ile ilgili Tanzimat döneminde başlayan faaliyetler, II. Meşrutiyet döneminde kadınların ekonomik özgürlüklerini kazanması yolunda atılan adımlar ve sağlanan eğitim olanakları ile devam etmiştir. Bu süreç aynı zamanda, örgütlü kadın hareketlerinin ve kadın derneklerinin de kuruluşunu doğuran bir süreçtir (Alkan vd. 1998: 88).

Dönemin hemen hemen bütün aydınları tarafından hürriyetin ilanı ve coşku ile kutlanması gereken bir bayram olarak değerlendirilen İkinci Meşrutiyet'e, kadınların yaklaşımı da farklı olmamıştır. Dolayısıyla II. Meşrutiyet'in ilanı ile kadınlar, çıkardıkları dergi sayısını artırmışlar, dernekler kurmuş ya da kurulan derneklere katılmışlar, siyasi partilerde aktif görevler almaya başlamışlardır (Tekeli 1982: 198'den akt. Özkiraz ve Aslanel 2011: 3; Toska 1994: 7). Bu dönemde kadına ülkenin modernleşmesinde ve ekonomik-kültürel kalkınmasında önemli roller biçildiğinden II. Meşrutiyet döneminde yaşayan aydınların istisnasız tamamı, kadın ve kadının toplumsal konumu ile ilgili fikirler ortaya koymuşlardır (Çaha 1996: 93).

Toplumun modernleşmesi konusunda kadına biçilen rol ve görevler, ülkenin kadim görüş ayrılıkları çerçevesinde şekillenmiştir. Muhafazakâr kanat kadının toplumdaki konumunun dini kurallara ve geleneklere uygun olarak devam etmesi yönünde fikirler beyan ederken, Batılılaşma taraftarları ise toplumun geri kalmasının en önemli sebeplerinden biri olarak kadının geleneksel konumunu görmüş ve kadının batılı tarzda özgür bir kimlikle sosyal hayata katılmasını savunmuşlardır (Kaplan 1999: 472; Kadıoğlu 1999: 120). Bu dönemdeki batılı tarzı benimseyen kadın cemiyetlerinde, kadının ailedeki statüsünün dışında kamusal alanda da etkin roller üstlenmesi gerektiği vurgusu hâkimdir (Çakır 1992: 239). Üçüncü bir görüş ise daha çok Ziya Gökalp tarafından dillendirilen İslamiyet öncesi Türk toplumundaki kadının konumuna yapılan vurgu olmuştur. Gökalpıe göre, Batıyı taklit ederek gerçekleşen kültürel bozulma ancak eski Türklerde var olan aile ahlakı anlayışının yeniden benimsenmesiyle tamir edilecektir (Gökalp 1997:139-146'den akt. Demir 1999: 111). Bu görüşten hareket edenler batılılaşmanın asrilik ile İslamcılık arasında gidip gelen aşırılıklarına karşı Türk ulusal kimliği ve terbiyesi ile sınır koymaya çalışmıştır (Göle 2000: 45). Kadına yönelik neşriyatlar da bu ayrımlaşmalar merkezinde çeşitlenmiştir. 
İkinci Meşrutiyet'in ilanından sonra başlayan kadın hareketi ve kadının toplum hayatına katımasının gerekliliği meselesi, çeşitli gazete ve dergilerde üzerinde durulan önemli bir konu haline gelmiştir (Akşit 2008). Íkinci Meşrutiyet'in özgürlükçü ortamı Osmanlıdaki kadın harekelerinin de önünü açmış, Batıdaki feminist akıma benzer hareket ve düşüncelerin savunulduğu dergi ve gazeteler ortaya çıkmıştır. Bu gazete ve dergiler, Batılı kadınların modern hayata ayak uydurmak için verdiği mücadelelere yer ayırarak, konuları Osmanlı kadınlarına örnek olacak şekilde işlemişler ve kadın meselesini, kadının eğitimi, toplum hayatına katııması, kadınların uğradıkları haksızlıklar gibi konularla gündeme getirmişlerdir (Toprak 1992: 230; Caporal 1982: 77'den aktaran Demir, 1999: 110). Kurnaz (1997), İkinci Meşrutiyet'ten sonra yayımlanan kadın dergilerini, yayın politikalarına ve dünya görüşlerine göre Batıcı ve Türkçü olarak iki grupta değerlendirmenin mümkün olduğunu ifade ederek, dönemin Batıcı kadın dergileri arasında: Mefharet, Demet, Mehasin, Kadınlar Dünyası, Hanımlar Alemi, Kadınlar Alemi, Osmanı Kadınlar Alemi, Kadın, Genç Kadın, Hanımlara Mahsus Gazete, Musavver Kadın; Türkçü kadın dergileri arasında; Kadınlık Hayatı, Kadınlık, Kadın Duygusu, Seyyale, Türk Kadını, Siyanet, Bilgi Yurdu Işığı, Bilgi Yurdu, Bilgi Mecmuası, Genç Kadın gibi dergileri saymaktadır (139-191).

Batıcı dergiler arasında en uzun soluklu olan (1913-1921) Kadınlar Dünyası, diğerlerinden farklı bir içeriğe sahiptir. O dönemin kadın dernekleri arasında en radikali olan Osmanlı Müdafaa-i Hukuk-ı Nisvan Cemiyeti'nin yayın organı olan dergi, toplumsal yaşamda kadının aktif olarak yer alması, kadın-erkek arasındaki eşitsizliğin kaldırıması, kadına boşanma hakkı verilmesi, mirasta kadının erkekle eşit paya sahip olması gibi konuları savunmuş ve gündeme getirmiştir (Çaha 1996: 101; Demirdirek 2011). Osmanlının ilk feminist kadınları arasında sayılan Nuriye Ulviye Mevlan'ın kurucusu olduğu dergi, sütunlarını sadece kadınlara açmış, kadınların hak ve hukuku tanınmadıkça erkek yazılarına yer verilmeyeceği ilkesini benimsemiş (Akyol 2012: 28) ve daha sonra Beynelmilel Kadınlar Cemiyeti'ni kurmuştur. Eğitimli ve özgür kadınların toplumsal hayata katılmalarının gerekli olduğu üzerinde duran dergi, toplumsal ve ekonomik hayatın gelişmesiyle kadının sahip olduğu statü arasında ilişki kurmuştur (Kurnaz 1997: 156; Gülcü ve Tunç 2012: 170). Kadın erkek eşitliğinin, kadın haklarının ‘Hukuk-ı Umumiye'de güvence altına alınmasıyla mümkün olabileceğine inanan Ulviye Mevlan hayatı boyunca toplumsal mekanizmanın kadın erkek eşitliği üzerine yeniden düzenlenmesi gerektiğini ısrarla vurgulamış ve bu görüşleri Cumhuriyet döneminde kadın haklarıyla ilgili kazanımlarda yaşam bulmuştur. Mevlan ayrıca, Osmanlıda, kadınların batıı toplumlarda olduğundan geri konumda olmasının temel nedeninin, feodal düşüncelerin oluşturduğu geleneksel aile ve bununla şekillenen toplumsal kültür olduğunu savunmuş, bu nedenle aile kurumunun sosyolojik olarak incelenmesi ve ıslah edilmesi gerektiğini vurgulamıştır (Kutlar 2008: 131). 
Türkçü ve muhafazakâr dergiler arasında ise başyazarı bir kadın olan (Nigâr Hanım) Kadınlık Gazetesi öne çıkmaktadır. Çağdaş Türk kadınını yetiştirmeyi amaçlayan dergi, özellikle Nigar Hanım'ın dilde sadeleşme hareketine destek vermesi bakımından da önem arz etmektedir (Gürsoy 1999:197-198'den akt. Özkiraz ve Aslanel 2011:5). Diğer yandan Hürriyet'in ilanından sonra çıkan ilk kadın dergisi olan ve İstanbul'da yayınlanan Demet Dergisi ise, kadın yazarlarıyla kadınlara hem siyaset ile ilgili bilgiler vermekte, hem de yeni dönemde kadınlara ve hükümete düşen görevleri hatırlatmaktadır. Nigar bint-i Osman, Jülide, Ulviye, Neziye, Şiven Peride, Ruhsan Nevvare, İsmet Hakkı Hanım, Halide Edib (Adıvar) gibi dönemin kadın aydınları arasında yer alan birçok isim derginin yazı kadrosu içinde yer almaktadır (Keskin 2005: 292).

II. Meşrutiyet sonrası çıkan kadınla ilgili diğer süreli yayınlar da şu şekildedir (Kurnaz, 1991: 86-94; Aşa, 1992):

İstanbul'da; Mehasin 1324-1325 (1908-1910), Kadın 1326-1328 (19101912), Musavver Kadın 1327 (1911), Kadınlar Dünyası 1329-37 (1913-1921), Hanımlar Alemi 1329-34 (1913-1918), Erkekler Dünyası 1329 (1913), Kadın Alemi 1330 (1914-15), Seyyale 1330 (1914), Kadınlık 1330 (1914), Kadınlık Hayatı 1331 (1915), Bilgi Yurdu Işığı 1332 (1916), Genç Kadın 1334 (1918), Genç Kadın 133435 (1918-19), Türk Kadını 1334 (1918), İnci 1335-39 (1919-1923). Selanik'de ise Kadın 1324-1325 (1908-1910).

\section{Kadınlık Gazetesi}

\subsection{Yöntem}

\subsubsection{Kapsam ve sınırlııklar}

Kadınlık Gazetesi, içinde haberler, dönemin aydınlarının kaleme aldığı yazılar, küçük hikâyeler, resim ve fotoğrafların olduğu bir gazetedir. Diğer yandan gazetede yer alan yazılar, kadının sosyal hayattaki yeri, görevleri, eğitimi, moda, saç bakımı gibi konuların yer aldığı Kısm-i içtimai, edebiyat, şiir ve müzik gibi konuların işlendiği Kısm-i edebi, mutfak bilgilerinin verildiği Tabahat ve dikiş, nakış gibi terziliğe dair konuların ele alındığı Terzilik olmak üzere dört kategoriden oluşmaktadır. Bu çalışma öncelikle gazetenin içeriğini oluşturan kategorilerden daha çok kadının kimliği ve toplumsal konumuna odaklanan yazıların kaleme alındığı Kısm-i içtimai'nin içeriğiyle sınırlandırımıştır. Böylelikle çalışmada gazetenin kadına biçtiği role ilişkin değerlendirmeler, daha çok kadının toplumsal konumuyla ilgili konulara ağırlık verilen Kısm-i lçtimai başlığı altında yer alan yazılar bağlamında ele alınmıştır. Diğer taraftan çalışmanın başka bir sınırlıı̆ı da kadın hareketi ve söylemini sadece Kadınlık Gazetesi ve bu gazetenin yayınlandığı dönem çerçevesinde ele almasıdır. Araştırmada kadın yazınına ilişkin eserler ve yayınların ilk olarak ortaya çıktığı Meşrutiyet dönemi Türkiye'de kadın hareketi açısından bir başlangıç ve emekleme süreci olarak ele alındığından bu dönemde 
oluşturulan kadın söyleminin diğer dönemlerdeki kadın hareketi veya söylemiyle karşılaştırılması yoluna gidilmemiştir8.

\subsubsection{Evren ve Örneklem}

Araştırmada Kadınlık Gazetesi'nin kadının toplumsal konumuna ilişkin nasıl bir yaklaşım sergilediğini anlamak için, çalışma kapsamına alınan kısm-i içtimai kategorisini oluşturan yazılardan örneklem alma yoluna gidilmiştir. Her bilimsel çalışmada veriler, araştırma soruları veya hipotezlere göre tanımlanmış örneklemden elde edilir. Bu çalışmada ise veriler olasılığa dayalı olmayan örnekleme tekniklerinden olan amaçsal örnekleme tekniğiyle belirlenen birimlerden toplanmıştır. Amaçsal örnekleme tekniğine göre veri toplanacak birimler çalışmanın amacı kapsamında araştırmacının yargı ve fikrilerine göre belirlenir (Maxwell, 1996: 70). Buna göre kısm-i içtimai bölümdeki 13 yazarın kaleme aldığı 7 adet okuyucu mektubuna cevap mahiyetinde olan mektup ve 22 makale olmak üzere toplam 29 yazı içerisinden, araştırmanın amacı ve araştırma sorularına göre tanımlanmış, konusu kadının toplumsal konumu ve rolüne ilişkin olan 10 yazı değerlendirmeye alınmıştır. Kadının sosyal yaşamdaki rolü hakkında dönemin fikrini yansıtacağına inanılan bu yazılar ise şunlardır: Ebussüreyya Sami'nin 'Bizde Kadınlık Zihniyeti', 'Kadınlıkta Terakki Var mı Yok mu?'; Halise Eşref'in 'Bir Hitabeden'; Şukufe Nihal Mithat'ın 'Bugünün Genç Kadınına'; Nevvare Şükran'ın 'Bizde Kadınsızlık ve Kadınlıkta Marifetsizlik' ve gazetenin sahibi olan Hacı Cemal'in 'Kadınların Mevkii', 'Tevlit ve idame-i nesil', 'Serbestiye-i Nisvan', 'Saadet-i Beşeriye Kadınla Kaimdir' ve 'íttihad-ı Nisvan Münasebetiyle'.

\subsubsection{Verilerin Toplanması ve Değerlendirilmesi}

Yukarıda ifade edilen araştırma sorularını yanıtlamak için öncelikle gazetenin Hakkı Tarık Us Kütüphanesi'nden temin edilen 8 Mart 1330-17 Mayıs 1330 tarihleri arasındaki orijinal Arap harfli Osmanlıca 11 nüshası, dijital ortama aktarılarak incelenmiştir. Çalışmada öncelikle kimlik bilgileri ve teknik özellikleri gibi gazeteye ait genel bilgiler sunulmuştur. Son olarak gazetenin kadına biçtiği rol(ler) üzerinde yorum yapabilmek ve derginin kadının konumuna ilişkin tutumunu ortaya koymak amacıyla, yazılarında kadının toplumsal konumuyla ilgili meselelere yoğunlaşan Ebussüreyya Sami, Halis Eşref, Şukufe Nihal Mithat, Mahmud Sadık, Nevvera Şükran ve Hacı Cemal'e ait yazılar niteliksel içerik analizi yöntemiyle incelenmiştir.

8 Her ne kadar bu dönemde ataerkillikle eklemlenerek oluşturulan kadın hareketi ve söylemi sonraki dönemlerde hatta günümüzde de devam etse de, yine de; siyasal, toplumsal ve ekonomik koşullar düşüldüğünde bu dönem kadın hareketi ve söyleminin diğer dönemlerle karşılaştırılmasının makul olmadığı düşünülebilir. 


\subsection{Künye ve Biçimsel Özellikler}

$1914^{9}$ Mart'ında yayınlanmaya başlanan ve her sayısı 16 sayfa olan Kadınlık Gazetesi'nin ilk sayısındaki başlığın üstünde yer alan bilgilere göre;

- Imtiyaz sahibi: Hacı Cemal

- Ser muharriri: Nigar Hanım

- Nüshası: 50 para

- Adres: Babıali caddesinde Orhan Bey hanında 8 numara

- Abone bedeli: Seneliği posta ücretiyle beraber 86, aylığı 50 kuruştur. Memalik-i ecnebiye için seneliği 35, altı aylığı 18 Franktır ("Mesleğimiz", Kadınlık, 8 Mart 1331, Numru 1, s.1.).

Altıncı sayıdan itibaren başığın hemen altındaki satırda gazetenin "heyet-i tahririye müdürü Nevvare Şükran" ifadesi yer almıştır. Yine birinci sayıda ve her sayıda tekrarlanan 'ihtar'da, gazeteye gönderilen yazıların yayınlansın yayınlanmasın iade edilmeyeceği hatırlatılmaktadır. Kendisini okuyucuya takdim ederken de şu cümleyi kullanmaktadır: "Kadınlığın varlığı ve memlekette bir mevkii bulunduğunu müdafaa eder, pencişenbe günleri neşr olunur musavver gazetedir."

Gazete, Perşembe günleri çıkacağını ilan etmiş olmasına rağmen, ilk sayısı 8 Mart 1330 Cumartesi günü, ikinci sayısı ise 13 Mart 1330 Perşembe günü yayınlanmıştır. 9, 10, 11. sayılar da Perşembe günü yayınlanmıştır. Dolayısıyla incelenen on bir sayının dört tanesi Cumartesi, yedi tanesi de Perşembe günleri yayınlanmıştır.

Gazetenin her sayısının ilk sayfasında genellikle Fransız sanatçılarına ait olan bir fotoğraf veya resim yayınlanmıştır. İç sayfalarda da bir durumu açıklayan ya da bir kıyafete örnek olarak verilen resim ve fotoğraflara yer verilmiştir.

Öne çıkan yazarları arasında; Ebussüreyya Sami, Hacı Cemal, Adviye Sıdkı, Aliye Haşmet, Aliye Mehmed, Azize Haydar, Bedriye, Cahide Cevdet, Eliye Suzan, Halide Nevzad, Halise Eşref, Hayriye Fitnat, Muazzez Salih, Nevvare Şükran, Nigar Cemal, Nilüfer, Raife Halii, Saliha Faruk, Şukufe Nihal ve Mehmed Sadık görülmektedir.

Gazetedeki yazılar, dört ana başlık altında yer almıştır.

Kısm-i içtimai: Kadının sosyal hayattaki yeri, görevleri, eğitimi, moda, el işleri ve saç bakımı gibi konularda yazılan yazıların yer aldığı bölüm. Kısm-i edebi: Edebiyat, şiir, hitabet, tefrika ve müzik konulu yazıların yer aldığı bölüm. Tabahat: Mutfak bilgileri ve yemek tarifleri gibi konular bu başlık altında yer almıştır. Terzilik: Gazetede 5. sayıdan itibaren yer alan bu bölümde, dikiş nakış, elbise

9 1914'de Kadınık'ın dışında hedef kitlesi kadınlar olan Kadınlar Alemi, Siyanet, Seyyale ve Kadınlık Duygusu gibi dergiler de yayına başlamışlardır (Akyol, 2012: 17). 
dikim tarifleri, renk seçimleri gibi konulara yer verilmiştir. Bu bölümler dışında, okuyuculardan gelen mektupların değerlendirildiği "Posta Kutusu" da gazetede yer alan bir diğer bölümdür.

\subsection{Kendi Dilinden Kadınlık Gazetesi'nin Çıkış Sebebi}

Kadınlık Gazetesi'nin ortaya çıkış nedeni kendi ifadeleriyle çok açıktır. İlk sayıdaki "Mesleğimiz" başlıklı yazıya göre amacı: kadının tefekkür dünyasında bir nur ve irfan tacı görmek, geçen senelerin, cehalet ve taassup içinde kararttığı kadınlık ufuklarını aydınlatmak, ona ilerlemesi için bir zemin hazırlamak ve bunu herkese duyurmaktır. Daha önceleri zihnen ve fikren felce uğramış kadının, layık olduğu konumu kazanması için ilimle donatılmasına ve onun da memleketinin kurtuluşu için bir nefes harcamasına destek olmaktır. Gazete, "dimağları paslandıran cehalet ve karanlığın yosunlarını, ilmin beyaz tırnakları ile söküp çıkartmağa" uğraşacağını iddia etmekte, her hafta okuyucularının takdirlerine sunacakları sayfalarının, onları daima aydınlatması temennisinde bulunmakta ve gelecek takdir ve iltifatlara da layık olacakları sözünü vermektedir ("Mesleğimiz", Kadınlık, 8 Mart 1330, Numru 1, s.2).

Yine "Mesleğimiz" başıkı yazıda yer alan ifadelere göre; gazete, kadınlara ait meydana gelen olayları tenkit etmeyecek ve yaymayacak, herhangi bir grubun sözcüsü olmayacak ve dengeli, orta yollu adımlarla ilerleyecektir. Meşahir-i Nisvan başlığı altında tarihin meşhur kadınlarını tanıtmakla, günümüz Osmanlı kadınlarının da büyük kadınlar olabileceği, tarihte görüldüğü gibi kadınlardan ülkelerini kurtaran kahramanlar, yazarlar, askerler, komutanlar, devlet yöneticileri, şairler çıktığı, dolayısıyla kadınların sadece dört duvar arasında yaşamaya mahkûm olmadıkları, silkinip kendilerine gelmeleri vurgulanmaya çalışılmıştır.

\subsection{Kadınlık Gazetesi'ne Göre Kadın}

Tesettür konusu, batılılaşma cereyanlarının başladığı ilk günlerden itibaren başlayan ve gittikçe harareti artan bir tartışma konusudur. Sadece kadın dergi ve gazeteleri değil, hemen her sosyal içerikli süreli yayın bu konuya temas etmiştir. Çakır'a göre dönemin aydınlarının gözünde, tesettür konusunun önemi sadece dini kaynaklı değildir ya da tesettür, kadınların sırf kocaları istiyor diye örtünmeleri demek değildir. Ayrıca devlet de sosyal düzenin korunması amacıyla, kadınların giyim kuşamı konusunda bazı kurallar koymuştur (Çakır 1994: 174). II. Abdülhamit döneminde yayınlanan İkdam Gazetesi de kadınların eğitimini bir görev sayarak, "kadının eğitimi, okutulması, analık görevi, çocuk bakımı, hamileliği, kılık kıyafeti, zarafeti, saç boyası, korse gibi pek çok konuda kadınlara faydalı bilgilere yer vermiştir." (Buttanrı 2003: 90).

II. Meşrutiyet'ten sonra, özellikle kadın dergi ve gazetelerinin artması, kadın gazeteci ve yazarların da yazı hayatında etkin bir şekilde rol almaya başlamasıyla bu tartışmanın daha da alevlendiği görülmektedir. Kadının sosyal statüsünün 
arzu edilen yere gelmesi ve kadının sosyal sorumluluk bilincinin artırılmasına yönelik bir yayın politikası benimseyeceğini ilan eden Kadınlık Gazetesi de bu tartışmada yerini almaktadır. Hemen ilk sayıda yer alan 'Bizde Kadın Zihniyeti' başııkı yazısında, Osmanlı kadını alışıımış kalıplardan kurtulmadıkça, kadınlığı ev işlerinden ve çocuklarına iş hazırlamaktan ibaret saymaktan vazgeçmedikçe, kadının sosyal statüsünde bir ilerleme kaydedilemeyeceğini ifade eden Ebussüreyya Sami özetle şunları söylemektedir (sadeleştirilmiş özet):

"Birisi, benim karımın, kızımın açık veya kapalı gezmesi, benden daha fazla niçin mahalle bekçisini ilgilendirsin der, diğeri gazete sayfalarından şöyle seslenir; ‘bu özel değil milli bir meseledir, geleneklerimizi unutmayalım'. Bunlardan birincisi mantıki, ikincisi sosyal olarak haklıdır. Fakat bu iki fikre karşılık bir üçüncü fikir lazımdır ki o da 'herkes erkek olsun kadın olsun sosyal mevkiini kendisi tayin etmelidir' fikridir. Bu da, aşağıdakileri uygulamakla mümkün olabilir.

Zihinler aydınlatılmak suretiyle değiştirilecek. Kadınlarımız henüz, batıı kadınların seviyelerine ulaşamamışlardır.

Bir Osmanlı kadınına, 'dünyaya niçin geldin' diye sorulsa, 'Allah'ıma ve padişahıma ibadet, kocama hürmet, evladıma muhabbet, için' der.

'Ev idaresi hakkında ne bilirsin' diye sorulsa, 'yemek pişirmek, ortalık süpürmek, dikiş dikmek, çocuklarımı, kocamı temiz giydirmek' diye cevap verir.

'Çocuklarınızın geleceği ilgili ne düşünüyorsunuz' sorusuna 'Mehmed'imi zabit, Osman'ımı rahmetli dedesinin mesleği olan naib, Hüseyin'imi de babası kendi kalemine alarak kâtip yapacak!' şeklinde cevap verebilir.

Biraz paradan, puldan, ekonomiden bahsetseniz, hemen 'a...a... para artırmak, para kazanmak, istikbali düşünmek kadının ne vazifesi?... kadın, erkeği ne getirirse onu harcar' diye mukabelede bulunur.

Bu kadınlara göre, iyi yedirmek, iyi giydirmek, gezdirmek, eğlendirmek erkeğin vazifesidir!

Daha sonra aynı seviyede iki hanımdan ayrı ayrı tesettür ve tesettürsüzlük ile ilgili fikirlerini sorunuz. Biri, 'erkeklerin sahip oldukları kadar hürriyet, kadınlara da sağlanmazsa denge olmaz dolayısıyla bu millet yükselemez', diğeri, 'üstüme iyilik, sağlık... ne çirkinliktir işitiyoruz. Kıyamet alametleri galiba.... Hiç erkek işine kadınlar karışır mı? Ne günlere kaldık, tövbeler olsun ya rab!....' diyecek.

Öncelikle, kadınların mevkilerini tayinden bahsedileceğine, fikri ilerlemeden, zihniyet değişikliğinden bahsedilmeli ve zihinleri aydınlatmaya çalışmalıdır. Bu zihniyet değişmezse, kadınların batıı anlamda bir kadın statüsü kazanmaları daha sonraki dönemlere ertelenecektir" ('Bizde Kadın Zihniyeti', Kadınlık, 8 Mart 1330, Numru 1, s.3-4).

Halise Eşref imzalı hitabet tarzı bir yazıda ifade edildiğine göre; yıllardan beri erkeklerin kadın üzerinde devam eden hâkimiyetinin kırılmasının zamanı gelmiştir. Bunu başaracak olan da kadının bizzat kendisidir. O, kendisini tam 
anlamıyla özgürleştirecek bu adımları atmazsa, gelecek neslin hafızasında çok kötü bir şekilde hatırlanmaktan kurtulamayacaktır.

"Ey kadın! Uyan, yeter artık hab u gaflet, uyan da mevcudiyetini helake sürükleyen erkek kibir ve nahvetini kır. İsbat-ı hüviyet eyle, varlığını göster ve anlat ki insanlığın zincir-i esarete tahammülü yok. Eğer ki kesret-i ülfet ve ünsiyetin hâsıl ettiği itibardan halasyab olmak içün çareye tevessül etmezsen, utan hacil ol ve emin ol ki ahlafın seni düşnam, yâdını bednam eyleyecekler." ("Bir Hitabeden", Kadınlık, 8 Mart 1330, Numru 1, s.6).

Yukarıda yazıları verilen Ebussüreyya Sami ve Halise Eşref'in fikirleri Osmanlı'daki kadın sorununun sadece kadının konumu ve cinsiyet ilişkileri değil, aynı zamanda kadınların cinsiyet rejiminden beslenen toplumsal iktidar biçimlerini derinden içselleştirmelerinden kaynakladığına dikkat çekmesi açısından önemlidir. Zira yazarların görüşlerinden kadının toplumsal konumunun iyileştirilmesi ve özgür kimliğini kurabilmesi sadece erkeklerden ya da yönetimden beklenecek bir iş değil, 'geleneksel rolünü kanıksamış kadın zihniyetinden' arınmayla gerçekleşebileceği yargısı çıkmaktadır.

Ebussüreyya Sami, ikinci sayının Kısm-i İçtimai bölümünde, kadınların hayatında bir ilerleme olup olmadığını tartışır. O'na göre kadınların hayatında ilerleme, hem vardır hem yoktur:

"Aziz dostlarım, kadınlıkta terakki var. Buna hiç süphe yok, içinden bir Madam Küri, bir Ümmü Sadık ve Nuri10, bir Fatma Aliye, bir Nigar binti Osman, bir Belkıs Şevket çıkan bir âlemde terakki yok demek güneşi inkâr kabilinden olur. A'sar-ı sabıkaya karşı asr-ı sabık, geçen asra da nispeten de asrı hazır, kadınlık için birçok esbab ve vesait-i terakki hazırlamıştır. Bu vesait ve vesaileden istifade etmeyi bilen kadınlarda, hakikaten eser-i terakki görülmüştür. Bugün garbın, en büyük darülfünunlarından birinde, hikmet ve kimya muallimliği vazifesini ifa eden ve (radyum) intiraında, müteveffa zevciyle beraber müşterekül mesai bulunan Madam Küri için kim diyebilir ki büyük validesiyle hemfikir ve hemhâldır? Belkıs Şevket Hanım kızımızın ceddesine "bir gün gelecek, senin ahfadından bir hanım kız, tayyare namı ile icad olunacak makineli bir kuşa binecek de fezalarda cevelan yapacak" denilseydi, hatuncağız ne cevap verirdi? Nasıl düşünürdü? Yine geçen asırda yaşayan bir vezir kızına, bir asır sonra yine bir vezir sülbünden, Fatma Aliye hanım isminde bir fazile yetişecek, erkeklerimize ders-i hikmet ve fazilet verecek yolunda bir şey çıtlatılsa idi kahkahalarla gülmez mi idi?" ('Kadınlıkta Terakki var mı Yok mu?' Kadınlık, 13 Mart 1330, Numru 2, s.2).

\section{Ebussüreyya Sami, Terakki (ilerleme) olmadığını da şu sözlerle izah etmiştir:}

"Ben şimdi size fikrimi izah ederken kendimi bir tayyare ile üç bin metre yükseğe çıkmış, bu âleme oradan bakmakta zan ediyorum. Ne görüyorum biliyor musunuz? Sema yere inmiş, fakat karanlık, muzlim, kasvetengiz, sim siyah bir

10 Yazarın dipnotu "Bunlar o kahraman validelerdir ki ciğerparelerinin en feci surette şehadetlerini duydukları vakit kendilerinden ziyade Osmanlı ordusunu şayan-ı taziye görmüşler idi". 
sema, ötesinde, berisinde tek tük yıldızlar parıldıyorlar, titrek ziyalarla Pertev Paşa olmak istiyorlar. Büyümek, büyümek ve nihayet ay olmak, güneş olmak arzusuna iraeye çalışıyorlar. Fakat ne mümkün, o istila-ı zulmet, $\mathrm{O}$ namahdut karanlık galebe ediyor, titrek ziyaları, mürteiş nurları söndüremese bile seyyahin-i daiminin pişgah-ı azmini tenvir kuvvetinden onları men'e muvaffak oluyor ve binnetice bir yokluk erz ediyor." ('Kadınlıkta Terakki var mı Yok mu?', Kadınlık, 13 Mart 1330, Numru 2, s.2-3).

Ebussüreyya Sami'ye göre; kadınların toplumsal konumuna ilişkin ilerlemeler vardır, ancak yeterli değildir. Yukarıda saydığı dönemin aydın kadınları kadınların ilerleyen yüzüdür. Fakat kadınlar dünyası, sadece önemli bazı Osmanlı şehirlerinde yaşayan, türlü imkânlara sahip bu aydın kadınlardan ibaret değildir. Gökte parlayan, bir kaç yıldız, bütün bir ülkeyi aydınlatmaya yetmez. Onların sayıları çoğalmalı ve gündüzleri güneş, geceleri de ay gibi yeryüzünü aydınlatmalıdılar.

Ebussüreyya ve Halise Eşref'in Osmanlı'daki kadınların toplumsal konumuna ilişkin gelenekçi yaklaşım dışındaki görüşlerine karşın, ilk sayıda yer alan, Şukufe Nihal imzalı hitabet tarzındaki yazıda kadının toplumsal konumunun iyileştirilmesi, onun aile ve ev içindeki rolünün etkinleştirilmesiyle ifade edilmiş, yani kadın iyi bir nesil yetiştiricisi olmak için eğitilmesi gereği vurgulanmıştır. Kadının konumunu verili cinsiyet rolleri çerçevesinde ele alan yazara göre, Osmanlı kadınının o günkü durumu tam bir felakettir. Cehalet karanlığı içinde hapsolmuş kadınlar, güçlerinin farkında değillerdir, vatan evlatlarının onlardan beklediği çok mukaddes vazifeleri vardır. Geçmişi unutarak üzerlerine serpilmiş ölü toprağını silkelemeli, evlatlarına rehberlik etmeli ve kaybettiklerine ağlamak yerine bütün gücüyle geleceğe bakmalıdır.

\begin{abstract}
"Fakat ağlama, münfail olma, artık samimi bir azm, müşa'şaş bir ümitle büyük gayene doğru yürü! Feyaz-ı ruhundan, onlara hakiki güneşler doğsun; biraz hayat bulsunlar; sonra onlar medeniyeti yavaş yavaş tanıyacaklar ve bir ihtiram-ı takdirkâr ile ellerini öperlerken, sen artık münevver bir istikbalin, ceyyid, şad, zihayat bir neslin en büyük hisse-i şeref ve inşirahını ruhunda his edecek, azab-ı ithamdan kurtulan pak cebininle, semada ebediyetlere kadar yükselecek, yükseleceksin." (Şukufe Nihal Mithat, "Bugünün Genç Kadınına", Kadınlık, 8 Mart 1330, Numru 1, s. 5).
\end{abstract}

Gazetenin ara sıra yazan yazarlarından Nevvare Şükran'a göre ise kadının çok şikâyet ettiğimiz durumundan yine kadınlar sorumludur. Daha çocukluğundan itibaren bir kız çocuğu, ileride evleneceği erkeğe nasıl hürmet ve hizmet edeceği konusunda eğitilmelidir. Ona göre genç kızlar evlerinde iyi terbiye edilmedikleri için, evlendiklerinde ev idare edemiyorlar, çocuk eğitemiyorlar. O'na göre gerilemenin ana sebeplerinden biri de budur.

"Âlemde terbiye-i maderane'nin ömr-ü beşer üzerindeki tesir-i mühimmini artık inkâr edecek kimse yoktur sanırım. Terbiye ve bilgisi mefkud değil, hatta noksan olan bir validenin ağuş-u cehlinde büyüyen çocuklardan elbette cahil ve şımarık bir unsur-u muzır teşkil eder ki: bu, memleket ve istikbal için bir izmihlal-i içtimai başlangıcı olmağa kâfidir. Memlekete bir nesl-i cedid-i münevver yetiştirmek 
için evvele bizi küçülten ve zayıflaştıran cehl ve taassup hastalıklarını tedavi eylemeğe mecburuz." ('Bizde Kadınsızlık ve Kadınlıkta Marifetsizlik', Kadınlık, 13 Mart 1330, Numru 2, s.4).

Gazetenin yazarları arasında bulunan H. C. İmzalı Hacı Cemal da kadınların eğitilmesi meselesini onun iyi bir anne ve eş olma rolü çerçevesinde ele almıştır. Ona göre kadın çocuklarını terbiye etmek, ev ekonomisini idare etmek ve ailenin sosyal münasebetlerini sağlıkı bir şekilde kurmasını sağlamak için eğitilmelidir.

\begin{abstract}
"Kadınsız hayat, kamersiz bir geceye teşbih edilecek derecede muzlumdur. Bu kavaid tahtınde yaşayan hemcinsimiz daima mesud ve daima müterakkidir. Kadın terbiyesi ki terbiye-i ibtidaiye dediğimiz validelerin çocuklarına ilka edecekleri zihniyet demektir. Hayat-ı beşerin istikbaline merbuttur. Terbiyesiz bir kadından tevellüt edecek çocuğun bazı istisnaiyetle cemiyet-i beşeriyeye ye hiç nef'i olamaz. Bunun için her şeyden akdem kadının terakki ve tahsil kavaidini kabul etmek lazım gelir. Şu halde kadın medeniyetin ve binnetice saadetin bir miyar-ı bibahasıdır. Cahil ve bir mevki-i içtimai sahibi olmayan kadınların mensup bulundukları kavim dahi mesut olamaz." ('Saadet-i Beşeriye Kadınla Kaimdir', Numru 6, s.2).
\end{abstract}

Yazar ayrıca bu yazısında kadının görevlerini şu şekilde sıralamıştır: "(1) tevlid ve idame-i nesl (Doğurmak ve neslin devamı), (2) terbiye-i etfal ve hakkı tahsil (Çocukların terbiyesi ve eğitim hakkı), (3) içtimai ve ailevi usul-ü muaşeret (Sosyal ve ailevi açıdan birlikte yaşama usulü), (4) idareye umur-i beytiye ve iktisat (Ev idaresi ve ekonomisi), (5) dört evvelki şeraitin ikmalinden sonra, mübareze-i hayat-ı maişetin aksam-ı basitesine dahil olmak" (Önceki dört şartın tamamlanmasından sonra normal gündelik hayatın geçim mücadelesine dahil olmak), (Saadet-i Beşeriye Kadınla Kaimdir, Kadınlık, 10 Nisan 1330, Numru 6, s.2)

Hacı Cemal "Kadınların Mevkii" başlıklı yazısında ise, kadınların ruh inceliğinin erkekleri geçtiği memleketlerde, insanlığın çok daha hızlı geliştiğini, eğer bir memleket tam anlamıyla medenileşmiş ise, orada mutlaka kadınların sosyal statüleri yüksek olduğunu vurgulamıştır. Yazara göre kadın ve erkek mukayesesini, kadın ve erkek eşitliği gibi meseleleri tartışmak anlamsızdır. Kadın ve erkek bir bütünün iki parçasıdır. Biri olmadan diğeri olamaz. Bizim bütün gayretimiz kadınlarımızın eğitimi için seferber olmalıdır. Eğer eğitimleri batıı kadınların seviyesine ulaşırsa, kadın erkek mukayesesi gibi gereksiz tartışmalar da ortadan kalkacaktır. Fakat kadınların eğitiminden, batıı kadınlar gibi aydınlık bir zihne sahip olmalarından, onların pespaye (tesettüre uygun olmayan) elbiseler giymesi anlamı çıkarılmamalıdır.

"Bugün bizim memleketimizde bazı kadınların giydiği elbiseleri, en medeni şehirlerden biri olan Paris'te bile rastlayamazsınız. Moda namı tahtındaki bu gibi çirkin kıyafetlere orada ancak artistler, şantözeler ve hayatı içtimaiyede bir mevkii bulunmayan kadınlar girmektedirler. Açık ve serbest gezmekte olan kadınların bile girmeğe tedip ettikleri bu karnaval kıyafetlerini, Türk hanımlarımızdan bazılarının nasıl kabul etmekte olduklarına hayret ediyorum! Binaenaleyh nail-i serbesiyet-i hukuk ancak meşru olabilir, gayr-i meşru talep edilen her şey mahkûmu 
akamettir. Zira Fransız'lar da gayet güzel bir darbı mesel vardır: Les hommes font les lois, les femmes font les moeurs 'Kadınlar ahlakiyatı ve erkekler kavanini tanzim ederler.'" (Kadınların Mevkii, Kadınlık, 3 Nisan 1330, Numru 5, s.3)

Yazara göre, Batıdaki ilerleme seviyesine sahip olmak için çalışmak, Batıı kadınları birebir taklit etmek demek değildir. İslam Dininin gereklerine uyarak da ilerleme kaydedilebilir.

\begin{abstract}
"Bazı hanımlarımızın iddia ettikleri gibi: -efendim erkekle kadının yekdiğerinden ne farkı vardır? Ricalin malik olduğu hukuk derecesine nisvanın dahi dâhil olması şarttır- faraziyelerini kabul edemeyiz. Çünkü Cenabı Hak kadınları erkekle teşrik-i mesai etmek için yaratmamıştır. Yukarıda tadat ettiğimiz beş şartın temini hüsn-ü devamı için yaratılmışlardır. Eğer kadınların erkekler gibi mübareze-i hayatiyeye dahil olmaları icap ediyorsa neslin terakki ve tekâmülüne kim hizmet edecektir? Vezaif-i beşer Şer'en, aklen ve mantıken tayin etmiştir. Bu usul ve kavaid tahtında hareket eden her kavim mesut ve nail-i refah olur. Aksi taktirde hercü merci-i daimi içinde yuvarlanarak bir gün ma'dum olur gideriz. Deminden beri dermiyan edegeldiğim nazariyat muvafık görülürse -ki şeriat bize bunu amirdir- mesudiyet-i beşeriye için her şeyden akdem yegâne çare kadınlarımızın tahsil ve tekemüllerine fevkalade dikkat ve itina etmek lazım gelir. Bittabi bu tahsil programına dâhil olacak beş evvelki şerait dairesinde tekâmül edecek nisvan-i müstakbeleden, memleket her şey ümid edeceği gibi yine bu münevver kadınlık sayesinde mesut olup ahfadımıza ilka edecekleri zihniyetle tam manasıyla tekemmül etmiş bir millet halinde, garblılar arasında bir mevki-i intiram elde edebiliriz." (Saadet-i Beşeriye Kadınla Kaimdir, Kadınlık, 10 Nisan 1330, Numru 6, s.2)
\end{abstract}

O dönemde yayınlanan kadın dergilerinin çoğunluğu, toplumsal ve tarihsel koşullardan dolayı feminizm konusuna batıda olduğundan çok farklı yaklaşmışlar, kadının çeşitli alanlarda çalışabilmesinin önünün açılması taraftarı olurken, kesinlikle kadın erkek eşitliği gibi bir tezi savunmamışlardır. Onlara göre kadının en önemli görevi iyi nesil yetiştirmektir, bunun için de en başta gerekli olan, iyi bir eğitim almalarıdır. H.C. bir önceki "Saadet-i Beşeriye Kadınla Kaimdir" başlıklı yazısının devamı olarak 7. sayıda kaleme aldığı "Tevlit ve İdame-i Nesil" başıkıkı yazısında da aynı konuya devam ederek kadının en önemli vazifesinin doğurmak ve neslin iyi bir şekilde devamını sağlamak olduğunu iddia etmektedir. O'na göre Yaratıcının erkek ve kadınlara emrettiği evliliğin gayesi, nüfusun çoğalması ve devamından başka bir şey değildir. Evlilikte aile hayatının kurucusu kadın, koruyucusu ise erkektir. Mutlu bir ailenin kurulabilmesi için kadın ve erkek birbirine tam güvenmelidir. Erkek kötü çevrelerde vakit geçirmemeli ve kazancına göre bir aile bütçesi oluşturmalıdır. Kadın ise kendisine emanet edilenleri kötüye kullanmamalıdır. H.C., aile içinde saadetin nasıl temin edileceğine dair bazı işaretler de verir. Buna göre erkeğin evine bağı olmaması kadının tavrından dolayıdır. Bütün gün çalışıp yorgun argın evine gelen bir erkeğe, evin hanımı, hemen eksiklerden, komşu kadının ev eşyalarının, elbiselerinin çok güzel olduğundan veya sen geçerken filan kadına bakmışsın gibi kıskançlık konularından bahsetmeye başlarsa, o erkeğin de zillet, sefalet ve ayyaşlığa düşmesi kaçınılmaz olur. Aile düzeninin devamı, 
kurallara uymakla ve ahlaki düşkünlükten uzak durmakla mümkündür. Bunun için devlete de bazı görevler düştüğünü H.C. şu şekilde ifade etmektedir.

"Bu münasebetsizlikler içinde talep edilecek her türlü hakkın su-i istimaline müncer olacağı ufak bir mülahaza ile anlaşılır. Bunun için her şeyden evvel tehzib-i ahlak ve tahsile gayret edilmelidir. Çünkü zamanımızda ekseriyetle kadın erkeklerin ber vech-i maruz kavaide katiyen riayetkar olmadıkları modaya olan şiddet-i inhimaklarıyla müsebbittir. Ve bu inhimak neticesinde tevlid-i neslin idamesine asla riayet edilmiyor. Zira müvellid, mani-i zevk ve safa!! ortada mutazarrır olan yine memleket... bu ahval-ı na merziyenin neticesi neslin inkıtaına kadar varıyor ki, telafisi çarelerini hükûmet acaba düşünmüyor mu?" ("Tevlit ve İdame-i Nesil", Kadınlık, 17 Nisan 1330, Numru 7, s.3).

Hacı Cemal'in kadınların özgürlüğünden ve serbestliğinden ne anlaşılması gerektiği konusunda da bazı tespitleri vardır. Ona göre kadının serbest olması demek, gazetelere yazı yazması, aile reisini dinlememesi, moda ile ilgili her konuya hemen atılması, yani her dilediğini yapabilmesi demek değildir. Tam aksine bunlar kadının serbestliği değil esareti anlamına gelir. Serbestlikten bugün bunların anlaşılması, ahlaken ne derece zayıf olduğumuzun göstergesidir. Serbestliğin ne olduğunu ise şu sözlerle anlatır "Kadınların serbest bulunmalarından maksat ve gaye, onları, maruz kaldıkları esaretten tahlis ile dört duvar arasında mahsur bir halde hava-yı şemsten mahrum ve mütenevvi emrazın zebunu, kurbanı olarak yaşamaktan kurtarmak çarelerini aramaktan ibarettir." ('Serbest-i Nisvan', Kadınlık, 26 Nisan 1330, Numru 8, s.2).

Cemal'e göre; eskiden beri Müslümanlarda, erkeğin her istediğini yapmakta hür, kadının ise daima susmaya mahkum edilmesi şeklinde bir anlayış vardır. Bu anlayışa şu sözlerle karşı çıkar:

"Biz erkekler kadınlardan büyük hangi meziyete malikiz? Para kazanıyor isek, onları (çalışmaya) bıraktık mı? Tahsil ediyor isek onlara müsade ettik mi? Teşkil-i aile ediyoruz, onlara bu hususta imtiyaz-ı mahsus bahşettik mi? Meşak ve mezahim veya zevk ve sefamıza, onları teşrik ettik mi? Velhâsıl kadınlara ne verdik ki ne istiyoruz? Hakkel insaf şöyle bir düşünür isek asıl biz erkekler idaresizliğimiz neticesi, kadınlığın bu tereddisine amil-i yegâne olduk ve bu kadar münakaşata rağmen el'an da bulunmakta berdevamız. Efsus ki, bu kaygısızlığımıza zavallı vatan kurban gidiyor... Bu gün ekseriyet denecek derecede kısm-ı uzmaya dâhil olan erkeklerimiz el'an kadınları esir-i mutlak telakki ediyorlar ve kadınları, yalnız koklanmağa mahsus bir gül ve fakat usanıldığında payimal-i hakaret olmağa mahkûm solmuş yapraklar menzilesinde bulunduruyorlar. ...Kadınlar, teşkil-i aileye memurdurlar, fakat aşçı, hizmetçi, çamaşırcı ve cariye değildirler." ('Serbest-i Nisvan', Kadınlık, 26 Nisan 1330, Numru 8, s.2).

Hacı Cemal aynı makalesinde kadınların serbestliği için erkeklere düşen görevleri de şöyle sıralar: Kadınların özgürlüğü için erkekler ilk olarak kadınları ağır ev işlerinden kurtarmalı ve bu konuda yardımcılar temin etmelidir. İkinci olarak hanenin bütün intiyaçları konusunda inisiyatifi kadına vermelidir. Ancak yanlış bir durumda erkek sadece uyarmakla yetinmelidir. Üçüncü olarak 
babalar sorumluluktan kaçmadan çocukların eğitimi ve terbiyesi konusundaki sorumluluğu kadına bırakılmalıdır. Dördüncü olarak kadının evleneceği kişiyi kendisinin seçmesine izin vermelidir. Beşinci olarak erkek, kadının ev idaresine yardımcı olmak ve ev işlerine yardımcı olmak için çalıştırdığı kişilerin hizmet bedelini ödemek için çalışmasına müsaade etmelidir. Altıncı olarak kadınların batılı giyim tarzı ile aşırı tesettür arasında, çarşaftan kurtularak daha modern bir tesettür giysilerle dolaşabilmesine izin verilmelidir. Yedinci olarak ise boşanmış kadınların, geçimlerini sağlamak amacıyla, kendi işlerini kurup çalışabilmelerine izin vermelidir. Yazar yukarıda erkeklerin yerine getirmesi gereken yedi şartın yanında sekizinci koşulu ise kadınlar için dile getirir. Ona göre kadın evliliğin devamı için iyi yemek yapabilmeli, eğitimli olmalı, temizliğe önem vermeli ve eşinin ilgisini çekebilmelidir. Hacı Cemal yukarıda sayılanların kabul edilip, yerine getirildiğinde kadınlığın ilerleyeceği ve geleceğin huzur içinde kurulacağını ifade etmektedir. "Bu ta'dat ettiğim sekiz şart kabul edilerek cihet-i tatbikiyesine başlandığı gün kadınlıkta terakki için mühim hutuvat atılmış olacaktır ki istikbalinde vatan refah bulur ve biz mesut yaşarız." ("Serbest-i Nisvan", Kadınlık, Numru 8, 26 Nisan 1330, s.2-3).

Meşrutiyetin ilk yılında Selanik'de çıkan Kadın dergisi ve onunla aynı dönemde İstanbul'da yayınlanan Demet ve Mehasin dergilerinde kadından, dinin icaplarını yerine getirmesi, ekonomiyi öğrenerek evini iyi idare etmesi, ülkesindeki ve dünyadaki gelişmeleri takip etmesi ve en önemlisi neslin sağlıklı bir şekilde devamını sağlamak için çocuklarını çok iyi bir şekilde eğiten iyi bir anne olması beklenir. (Denman, 2009: 76). II. Meşrutiyet ilan edildikten sonra çıkan hemen hemen bütün süreli yayınlar, kayıtsız şartsız, İttihat Terakki taraftarıdır. Adı geçen dergilerde yer alan fikirler de İttihat Terakki ile örtüşür, hatta bunlar, İttihat Terakki'nin Osmanlı kadınının ilerlemesi konusundaki fikirlerini yaymakla görevli yayın organıymıs gibi yayın politikası takip ederler. Yukarıdaki bölümlerde ifade edildiği gibi, onlardan altı yıl sonra yayın hayatına başlamasına rağmen Kadınlık Gazetesi'nin misyonu da farklı değildir. İstisnasız bütün sayılarında kadının gelecek nesilleri terbiye görevine dikkat çekilir. Kısm-i İçtimai bölümünde Ebussüryya Sami, Hacı Cemal ve Mahmud Sadık tarafından yazılan yazıların tamamı da bu konuyla ilgilidir. Hacı Cemal'in şu ifadesi de bunu ispat eder niteliktedir: "Kadınlar çalışmalı, fakat ne için bilir misiniz? Hürriyetlerini istihsal ile beraber vatanı müstefit edebilecek hayırlı evlatlar, iş görecek torunlar ve muhitimizi i'mar edecek fedakârlar yetiştirmek için çalışmalıdırlar." ('İttihad-ı Nisvan Münasebetiyle', Kadınlık, 17 Mayıs 1330, Numru 11, s.2).

Hacı Cemal, Fransızların Doğu kadınlarıyla ilgili söylediği "Doğunun kadınları, ev eşyasından sayılırlar" sözüne dikkat çekerek bir esir gibi evlere hapsedilen kadını, bu esaretten kurtarmadıkça her hangi bir ilerlemenin sağlanamayacağını ifade eder. O'na göre kadınlar esaretten kurtulmak için birleşmelidir. Bunun için Osmanlı Devleti sınırları içinde yaşayan bütün kadınların birliğini sağlayacak "İttihad-ı Nisvan" adında bir dernek kurulmasını teklif ederek derneğin gerekliliğini şöyle açıklar: 
"Nisvanı evc-i balay-i terakkiye isale hasr-ı vücud ile çalışan mahdut cemiyetler vasıtasıyla matlup neticeye vasıl olunmayacağı ufak bir mülahaza ile pek tabi olarak anlaşılır. Gurupların tezayüdü ittihadı takviye eder ve binnetice her türlü metalibat-ı muhikkanın cihet-i terviciyesi istikmal edilmiş olur ki bidayet-i teşekkülde tesadüf edilecek birçok mevania ve müşkülata bir azm-i metinane ile mütevekkil bir surette mukavemet etmek lazımdır. Aksı takdirde hiçbir şeye muvaffakiyet imkânı yoktur ve neticesi tereddi-inhitattır." ('Ittihad-ı Nisvan', Kadınlık, 3 Mayıs 1330, Numru 9, s.2,3).

Derneğin kurulması için memleketin her tarafındaki kadınlardan cevaplar beklediğini, yeterli sayıya ulaştıklarında derneği kurmak için gerekli başvuruları yapacağını bildiren $\mathrm{Hacı} \mathrm{Cemal}$, bu çağrısına yeterli olumlu tepkiler alamamıştır. Bunu son sayıdaki yazısında şu şekilde ifade etmiştir:

\begin{abstract}
"Kemal-i teessüfle kaydından sarf-ı nazar edemeyeceğimiz bir nokta varsa o da ashab-ı müracaatın pek mahdut bir halde kalmış olması cidden nazar-ı dikkati caliptir. Fakat işte biz azim ve niyetimizde sebat etmiş olmak için teşkilata mübaşeret ediyoruz. İçtimaiyatta adetler hüceyrat gibi tekessür-ü tabiiye merbutturlar. Adeta bir çığ gibi yuvarlandıkça cesamet peyda eder. Binaenaleyh bugün mahdut bir kısımla işe başlandığı halde bir gün gelecektir ki, bütün kitle-i nesviyetle maksat ve meramı takip edeceğiz. Kadınlık, evet bu muhterem nam-ı ulvi yalnız tebessüm, şiir okumak ve şarkı terennüm etmek için yaratılmış addedilmesin. Arzu edildiği takdir de bir nağme halinde harim-i muhita dahi titreyebilir. Çünkü hemcinsiniz sizden meserretamiz haberlere intizar ediyor. Siz sa'yınızla onlara müjdeler vererek hakikaten ölmeyeceğini ispat etmeniz lazım gelir... Her talep bir hakka müstenit olup hak ise ancak taharri ve yorulmakla elde edilebilir." ('Itttihad-ı Nisvan Münasebetiyle', Kadınlık, 17 Mayıs 1330, Numru 11, s.2).
\end{abstract}

Gazetede, kadınların ilerlemesinden ne anlaşılması gerektiği konusunda ileri sürülen fikirler yazarlar arasında farklılık göstermektedir. Ebussüreyya ve Halise Eşref kadınların toplumsal manada ilerlemesi için kadının bir özne olarak ön plana çıkması ve kadınların ev işıleri dışındaki konularda da eğitilmesini, erkeklerin çalıştığı her alanda çalışabilmesini, sosyal hayatta yer almasını savunurken Şukufe Nihal, Hacı Cemal, Mahmud Sadık ve Nevvare Şükran gibi yazarların yazılarında ana tema ise kadınların ev işlerinde marifetli ve donanımlı olması ve eğitilmesi halinde toplumun ilerleyebileceği olmuştur.

\title{
5. Sonuç
}

Tanzimat'la başlayan ve II. Meşrutiyet dönemini de kapsayan süreçte kadınlara yönelik çıkarılan ve sayıları her geçen gün artan çeşitli neşriyatla Batılılaşmanın bir gereği olarak kadınların mevcut konumları sorgulanmış, toplumsal geri kalmışlığın faturası kadının eğitimsizliğine ve geleneksel konumuna kesilmiştir. Bu çalışmada incelenen Kadınlık Gazetesi'nde de toplumsal gerileme ile kadının toplumsal konumu arasında bağlantı kurulmuş ve kadının toplumsal rolüne yönelik çeşitli görüşler dillendirilmiştir. Bu çerçevede gazete, dönemin şartlarına uygun olarak, kadın konusunu özellikle eğitim, evlilik ve boşanma hukuki 
ile ilgili adaletsizliklerin giderilmesi ve kadınların çalışabilmesi gibi meseleler üzerinde ele almıştır.

Değerlendirme sonucunda gazetenin yazarları arasında kadının eğitimi, kimliği ve konumuna ilişkin farkı bakış açıarının varlığı dikkat çekmiştir. Öyle ki kadın söyleminin genelde verili cinsiyet rolleri bağlamında belirlendiği gözlemlense de yer yer kimi yazarlarca bu sınırların zorlanarak yeni bir söylem oluşturma çabasında olduğu anlaşılmıştır. Örneğin gazetenin sahibi olan Hacı Cemal ile birlikte Şukufe Nihal, Mahmud Sadık ve Nevvare Şükran gibi yazarlar kadınların toplumsal konumuna ilişkin rollerini ev ve aile içi alanlarla sınıllarken, Ebussüreyya Sami ve Halise Eşref ise kadınların toplumsal manada ilerleyebilmesi için kadının bir özne olarak ön plana çıkmasını ve kadınların ev işleri dışındaki konularda da eğitilmesini, erkeklerin çalıştığı her alanda çalışabilmesini, sosyal hayatta yer almasını dile getirmişlerdir. İncelenen yazılar çerçevesinde ilk gruptaki yazarların kadınların kimliği ve konumuna ilişkin yaklaşımları aşağıdaki şekilde özetlenebilir:

- Kadının öncelikli görevi çocuk yetiştirmektir. Milletlerin geleceği çocuklar ise onları eğitmekten daha mühim bir iş olamaz. Zira bir kadın için evi ve çocukları ile meşgul olmaktan daha mukaddes bir meşguliyet yoktur.

- Kadınların da erkekler gibi çalışmaya hakları vardır. Ancak kadınlar ya ailenin geçimi ve ev idaresini yardımcı olmak amacıyla ya da boşanan kadının kendi ayakları üzerinde durabilmesi için çalışmalıdır.

- Kadınların eğitimi erkeklerin eğitiminden daha önemlidir. Kadın eğitilmeli, iyi bir eş, iyi bir anne ve evi idare edebilecek ekonomik bilgilere sahip olması sağlanmalıdır. Çünkü onlar neslin devamı olan çocukların terbiyecisidirler ve bu görevlerini ne kadar iyi yaparlarsa milletin geleceği o kadar aydınlık olur.

Bu görüşler değerlendirildiğinde kadınlara biçilen nesil yetiştiriciliği rolünün ataerkilliğin dışına çıkmadığı anlaşılmaktadır. Öyle ki toplumsal değişim bağlamında kadına modernleşmenin taşıyıcılığı rolü verilmiş olsa bile, bu rolün sınırları erkekler tarafından çerçevelenmiş, kadının kimliği ve özgürlüğü ev ve aile içi bağlamda ele alınmıştır. ${ }^{11}$ Kadının geleneksel rollerine ilişkin verili yapıyı sorgulamadan dile getirilen bu talep ve görüşler ataerkillikle eklemlenen bir kadın söylemi oluşturmuşlardır.

11 Cumhuriyet ve sonrası dönemde bu yaklaşım devam etmiş, bu görüşü benimseyenler kadınların ev dışında çalışmalarının toplumun düzeni ve ahlak yapısını bozacağını vurgulayarak, kadınların asıl işi olan analığın aksatımasına neden olacağını savunmuşlardır (Sancar 2012). Cumhuriyet ideolojisiyle birlikte her ne kadar kadına yönelik haklar tanınsa da kadınlara yüklenen ataerkil rol ve sınıflandırmalar hala bugün dahi devam etmektedir. Cumhuriyet'in ilk dönemlerinde kadın varlığı her şeyden önce çocuğu için iyi bir anne, vatanı için çalışkan ve yurtsever bir yurttaş olarak anlamlandırılıyordu (Sarıtaş ve Şahin 2015: 645-646). 
Diğer yandan Ebussüreyya Sami ve Halise Eşref'in yer aldığı ikinci grup yazarlar ise, kadın özgülügünü, ev içi sınırlılı̆ından kurtararak, daha kamusal bir düzlemde değerlendirmişlerdir. Onlara göre daha önceki dönemlerde olduğu gibi kadını eve hapseden, ev işlerinden başka iş gördürmeyen, boşandığı zaman kendi geçimini kazanacak bir donanıma sahip olmasını engelleyen zihniyet artık terk edilmelidir.

Sami ve Eşref kadınların konumlarının bu denli kötü olmasını, kadınların ataerkil yapıyı derinlemesine içselleştirmiş zihniyet yapılarına bağlamaktadırlar. Bu zamana kadar katı bir disiplin altında tutulan kadınlardan ilerleme ve uygarlık için katkı beklenilmesinin yanlış olduğunu belirten yazarlar, kadınların toplumsal konumunun ilerlemesi ve erkek hâkimiyetinin kırılması için öncelikle kadınların zihniyetinin değişmesi gerektiğini vurgulamışlardır. Bu bağlamda yazarlar kadının toplumsal rolünün değişmesi için bizzat kadının uyanması ve harekete geçmesi gerektiğini ifade etmektedirler. Yazarların bu görüşlerinin altında, örtülü bir şekilde, toplumsal geri kalmışlığın nedeni olarak bizzat kadınlar işaret edilmektedir. Zira kadın bu kadar eğitimsiz, bu kadar pasif olduğu için toplum geri kalmıştır ve batı medeniyetini yakalayamamıştır. Ayrıca yazarların, eleştirdikleri kadın zihniyetini oluşturan tarihsel ve toplumsal koşulları ve bu koşullar içerisinde sürekli kendini üreten erkek egemen zihniyeti gözden kaçırmış oldukları söylenebilir. Yine de zamanın baskın toplumsal yapısı göz önüne alındığında Ebussüreyya Sami ve Halise Eşref'in fikirleri Osmanlı'daki kadın sorununun sadece kadının konumu ve cinsiyet ilişkileri değil, aynı zamanda kadınların cinsiyet rejiminden beslenen toplumsal iktidar biçimlerini derinden içselleştirmelerinden kaynakladığına dikkat çekmesi açısından son derece önemlidir.

Ancak diğer yandan dönemin kadın erkek eşitliği ya da kadının toplumsal konumuna ilişkin yaklaşımı ile günümüz yaklaşımı ve Batı'daki gelişmeler arasında kıyaslama yapmak yanlıştır. Çünkü her türlü toplumsal gelişme kendi tarihsel ve toplumsal koşulları çerçevesinde değerlendirildiğinde anlamlı olur. Osmanlı kadın hareketi öncelikle kadının aile içindeki konumuna, eğitim, evlilik ve boşanma hukukundaki adaletsizliklere eğilmiş, sonrasında kadının toplumsal konumunun iyileştirilmesine yönelik din ve toplum kuralları ve devletin yapısının dönüşümü için mücadeleye girmiştir. Bu dönem kadın hareketi kadınların aile içi konumlarının kadınların düzeltilmesinin yanında toplumsal yaşama dahil olmalarının meşru zeminini oluşturma çabasında olmuştur. Bu mücadele elbette ki Batı'daki kadın hareketinden farkı ve yavaş biçimde siyasallaşmıştır. Kadınların aile içi ve toplumsal dönüşümü için öncelik verilen ilk şey eğitim olmuştur. Dönemin en büyük probleminin eğitimsizlik olduğu göz önüne alındığında bu vurgu daha net anlaşılmaktadır. Öte yandan gerek bizzat hak arayışı mücadelesine girecek eğitimli kadın sayısının az oluşu ve gerekse toplumsal ve siyasi yapının henüz hazır olmayışı gibi nedenlerle kadınların toplumsal konumlarının iyileştirilmesi ve kamusal görünürlüklerinin artırımasına yönelik konular, pratiğe dökülmesinden ziyade tartışmaya açıımasıyla sınırlı kalmıştır. Daha sonraki dönemler de ise kadın hareketleri ve söylemi daha çok kamusal alana dahil oluş şekilleri belirlenmesi, 
kanunlarla kadına verilen hakların toplumsal yaşama geçmemesi12, ücret politikalarında cinsiyet farkıııkları ve siyaset dünyasında kadın varlığı gibi sorunlar üzerinde durmuştur (Arat, 1998; Berktay, 1998; Kılıç, 1998; Toksa, 1998; Yaraman, 2001; Bayrakçeken, 2004; Sancar, 2004; İşat, 2006; Akşit, 2008; Zihnioğlu, 2009; Oruç, 2010; Makal, 2012: 40-45).

Kadınlık Gazetesi ve benzerleri gibi yayınlar kadınların bir asır öncesinde başlattıkları sosyal, ekonomik, kültürel ve siyasal alanda var olma mücadelesini, dönemin şartları çerçevesinde anlamak ve kadın hareketlerinin günümüzdeki konuma erişmesi açısından oluşturdukları alt yapı bağlamında önemli ve değerlidir. Kadınlık Gazetesi bir yandan hakim ataerkil söylemleri reformist bağlamda yeniden üretirken diğer yandan cılız da olsa dönemin kadın yaklaşımına karşı eleştirel bir feminist söylem geliştirmiştir. Bu dönemki kadın hareketinin kadının toplumsal konumuna ilişkin kurduğu söylem, kendinden sonraki dönemlerin kadın söyleminin temelini oluşturmuştur. Bu bağlamda kadın hareketine kuşaklararası aktarım ve geçişler açısından bakılması daha anlamlı olacaktır. Bu yüzden de kadınların toplumsal mücadelelerini bulundukları tarihsel ve toplumsal koşullarda anlamak ve günümüzle bağını kurabilmek için bu tür araştırmaların çoğalması gerekmektedir.

\section{Kaynakça}

AKDENiZ Safiye (2008), "Tanzimat Dönemi Edebiyatçılarının Kadın Problemine Yaklaşım Biçimleri", Ege Üniversitesi Türk Dili ve Edebiyatı Araştırmaları Dergisi, Sayı. 15, ss. 1-32.

AKŞıT E. Elif (2008), "Osmanlı Feminizmi", Uluslararası Feminizm ve Doğu Kadınları, Doğudan, Sayı. 7, ss. 84-91.

AKYOL Hüseyin (2012), Aykırı Kadınlar (Osmanlı'dan Günümüze Devrimci Kadın Portreleri), Ankara, Imge Kitabevi.

ARAT Yeşim (1998), “Türkiye'de Kadın Milletvekillerinin Değişen Siyasi Rolleri, 1934-1980", 75 Yılda Kadınlar ve Erkekler, (Der) A. Berktay, İstanbul, Tarih Vakfı Yayınları, ss. 249-267.

AŞA Emel (1992), 1869-1923 Yıları Arasında Yayımlanan Türk Kadın ve Aile Dergileri', Sosyo Kültürel Değişme Sürecinde Türk Ailesi, C. 3, Ankara, ss. 966978.

BAYRAKÇEKEN T. Gökçe (2004), Being and Becoming Professional: Work and Liberation Through Women's Narratives in Turkey", Yayınlanmamış Yüksek Lisans Tezi, Ankara, ODTÜ Sosyal Bilimler Enstitüsü.

12 Bu konuda örnek olarak 1950'de İş Kanunu'nda yapılan değişiklikle ücret politikalarında cinsiyete dayalı eşitsizlik ortadan kaldırılmıştır. Ancak uygulamada bunun gerçekleşmesi uzun süre mümkün olmamıştır (Makal, 2012). 
BERKTAY Fatmagül (1998), "Cumhuriyet'in 75 Yıllık Serüvenine Kadınlar Açısından Bakmak", 75 Yılda Kadınlar ve Erkekler, Der. A. Berktay, İstanbul, Tarih Vakfı Yayınları, ss. 1-13.

BORA Aksu ve KONDiYOTi Deniz (2000), Cariyeler, Bacılar, Yurttaşlar, İstanbul, Metis Yayınevi.

BUTTANRı Müzeyyen (2003), İkdam Gazetesinin Kültür Hayatımızdaki Yeri, Şekil ve İçerik Özellikleri (1894-1900). Eskişehir Osmangazi Üniversitesi Sosyal Bilimler Dergisi, Cilt: 4 Sayı. 1, ss. 77-97.

ÇAĞLAYAN Hale (2002), Defining Ottoman Women: The Terakki-i Muhadderat (1869-1870) as the First Women's Journal in the Ottoman Empire, Yayımlanmamış Yüksek Lisans Tezi, Orta Doğu Teknik Üniversitesi, Sosyal Bilimler Enstitüsü.

ÇAHA Ömer (1996), Sivil Kadın, Ankara, Vadi Yayınları.

ÇAKIR Serpil (1992), II. Meşrutiyet Devri Kadınlarının Aile Anlayışları, Sosyo Kültürel Değişme Sürecinde Türk Ailesi, C. 1, Ankara, ss. 238-251.

ÇAKIR Serpil (1994), Osmanı Kadın Hareketi, İstanbul, Metis Yayınları.

DEMiR Ö. Nilüfer (1999), II. Meşrutiyet Dönemi Osmanlı Feminizmi, Hacettepe Üniversitesi Edebiyat Fakültesi Dergisi, Cilt 16, Sayı. 2, ss.107-116.

DEMiRDiREK Aynur (2011), Osmanlı Kadınlarının Hayat Hakkı Arayışının Bir Hikayesi, İstanbul, Ayizi Kitap.

DENMAN K. Fatma (2009), ikinci Meşrutiyet Döneminde Bir Jön Türk Dergisi: Kadın, İstanbul, Libra Kitapçlık ve Yayınclık.

DIŞBUDAK Müge (2008), Türk Kadınlar Birliği, Yayınlanmamış Yüksek Lisans Tezi, İzmir: Dokuz Eylül Üniversitesi Atatürk Illkeleri ve Inkılap Tarihi Enstitüsü.

DURAKBAŞA A. Nilüfer (1998), Cumhuriyet Döneminde Modern Kadın ve Erkek Kimliklerinin Oluşumu: Kemalist Kadın Kimliği ve 'Münevver Erkekler', 75 Yılda Kadınlar ve Erkekler, Der. A. Berktay Hacımirzaoğlu, Ankara, Tarih Vakfı Yayınları, ss. 29-51.

GÖLE Nilüfer (2000), Modern Mahrem, İstanbul, Metis Yayınevi.

GÜLCÜ Erdinç ve TUNÇ Samiye (2012), Osmanlı Basın Hayatında Kadınlar Dünyası Dergisi, Çankırı Karatekin Üniversitesi Sosyal Bilimler Enstitüsü Dergisi, 3(2), ss. 155-176.

iŞAT, Ceren (2006), Türk Kadınlar Birliğinde Devlet ve Sınıfilişkileri, Yayınlanmamış Yüksek Lisans Tezi, Ankara, A. Ü. Sosyal Bilimler Enstitüsü.

KADIOĞLU Ayşe (1999), Cumhuriyet Idaresi Demokrasi Muhasebesi, Ankara, Metis Yayınları. 
KAPLAN Leyla (1999), II. Meşrutiyet Dönemi Osmanlı Kadınlarının Özgürleşme Hareketi, Osmanlı Ansiklopedisi, Cilt. 5, Yeni Türkiye Yayınları, Ankara, ss. 446473.

KARACA Şahika (2011a), Fatma Aliye Hanım'ın Türk Kadın Haklarının Düşünsel Temellerine Katkıları, Karadeniz Araştırmaları Dergisi, Güz, Sayı. 31, ss. 93-110.

KARACA Şahika (2011b). Modernleşme Döneminde Bir Kadın Yazarın Portresi: Emine Semiye Hanım, BILIG, ss.115-134.

KARACA Şahika (2013), Fatma Aliye ve Emine Semiye'nin Kadının Toplumsal Kimliğinin Kazandırılmasında Öncü Fikirleri, The Journal of Academic Social Science Studies, Volume 6, Issue 2, ss.1481-1499.

KESKIN Tülay (2005), Demet Dergisi'nde Kadın ve Illerleme Anlayışı, Tarih Araştırmaları Dergisi, Cilt. 24, Sayı. 37 ss. 289-312.

KILIÇ, Zülal (1998), Cumhuriyet Türkiye'sinde Kadın Hareketine Genel Bir Bakış, 75 Yılda Kadınlar ve Erkekler, Der. A. Berktay, İstanbul, Tarih Vakfı Yayınları, ss. 347-360.

KURNAZ Şefika (1991), Cumhuriyet Öncesinde Türk Kadını (1839-1923), Ankara, T.C. Başbakanlık Aile Araştırma Kurumu Başkanlığı Yayınları.

KURNAZ Şefika (1997), Cumhuriyet Öncesinde Türk Kadını (1839-1923), İstanbul, MEB Yayınları.

MAKAL Ahmet (2012), “Türkiye'de Kadın Emeğinin Tarihsel Kökenleri: 19201960", Geçmişten Günümüze Türkiye'de Kadın Emeği, (Der) Ahmet Makal ve Gülay Toksöz, Ankara, A.Ü. Yayınevi. ss. 38-116.

MAXWELL A. Joseph (1996), Qualitative Research Design: An Interactive Approach, Thousand Oaks, Sage Puplications.

ORUÇ G. Selin (2010), Türk Kadınlar Birliği (1924-1935), Yayınlanmamış Yüksek Lisans Tezi, Ankara, Hacettepe Üniversitesi Sosyal Bilimler Enstitüsü.

ÖZKIRAZ Ahmet ve ASLANEL M. Nazan (2011), İkinci Meşrutiyet Döneminde Kadın Olmak, Sosyal ve Beşeri Bilimler Dergisi, Cilt. 3, No. 1, ss. 1-10.

ÖZÖN M. Nihat (1997), Namık Kemal ve ibret Gazetesi, İstanbul, Yapı Kredi Yayınları.

SANCAR Serpil (2012), Türk Modernleşmesinin Cinsiyeti: Erkekler Devlet, Kadınlar Aile Kurar, İstanbul, İletişim Yayınları.

SANCAR, Serpil (2004), "Otoriter Türk Modernleşmesinin Cinsiyet Rejimi", Doğu Batı, ideolojiler II, Sayı. 29, ss.197-211.

SARITAŞ Ezgi ve ŞAHIN Yelda (2015), Ellili Yıllarda Kadın Hareketi, Türkiye'nin 1950'li Yılları, Der. Mete Kaan Kaynar, İstanbul, İletişim Yayınları, ss. 627-667. 
TOKSA, Zehra (1998), "Cumhuriyetin'in Kadın İdeali: Eşiği Aşanlar ve Aşamayanlar", 75 Yılda Kadınlar ve Erkekler, Der. A. Berktay, İstanbul, Tarih Vakfı Yayınları, ss. 71-88.

TOSKA Zehra, ÇAKIR Serpil, GENÇTÜRK Tülay, YILMAZ Seher, KURÇ Selmin, ART Gökçen, DEMiRDiREK Aynur (1993), Istanbul Kütüphanelerindeki Eski Harfli Türkçe Kadın Dergileri Bibliyografyası (1869-1927), İstanbul, Metis Yayını.

YARAMAN Ayşegül (2001), "Durgunluk Döneminde Cüretkar Talepler Kadın Gazetesi", Toplumsal Tarih (3), ss. 36-42.

YAŞAR T. Fatma (2008), Osmanlı Kadınının Eğitimine Yönelik IIlk Süreli Yayın: Terakki-i Muhadderat, Değerler Eğitimi Merkezi Dergisi, (3), ss. 98-105.

YÜCEKÖK N. Ahmet, TURAN iliter ve ALKAN Ö. Mehmet (1998), Tanzimattan Günümüze Istanbul'da STK'lar, İstanbul, Tarih Vakfı Yayınları.

ZIHNIOĞLU Yaprak (2009), "Kadın Kurtuluşu Hareketinin Siyasal İdeolojiler Boyunca Seyri", Modern Türkiye'de Siyasi Düşünce, Dönemler ve Zihniyetler, Cilt. 9, Ed. Tanıl Bora ve M. Gültekingül, İstanbul, İletişim Yayınları, ss. 805-817.

\section{Gazeteler}

'Mesleğimiz', Kadınlık, 8 Mart 1330, Numru 1, s. 2

'Şayan-ı Teessüf Bir Mülakat', Hukuk-ı Umumiye Gazetesi, 15 Teşrin-ievvel 1908, no 30 , s. 1

Ebussüreyya Sami, 'Bizde Kadın Zihniyeti' Kadınlık, 8 Mart 1330, Numru 1, s. 3-4

Ebussüreyya Sami, 'Kadınlıkta Terakki var mı Yok mu?' Kadınık, 13 Mart 1330, Numru 2, s. 2

Ebussüreyya Sami, 'İnsanlarda Halet-i Ruhiye', Kadınık, 20 Mart 1330, Numru 3, s. 2

Hacı Cemal, 'Saadet-i Beşeriye Kadınla Kaimdir', Kadınlık, 10 Nisan 1330, Numru 6, s. 2

Hacı Cemal, 'Tevlit ve İdame-i Nesil', Kadınlık, 17 Nisan 1330, Numru 7, s. 3

Hacı Cemal, 'íttihad-ı Nisvan', Kadınık, 3 Mayıs 1330, Numru 9, s. 2-3

Hacı Cemal, 'Itttihad-ı Nisvan Münasebetiyle', Kadınlık, 17 Mayıs 1330, Numru 11, s. 2

Halise Eşref, 'Bir Hitabeden', Kadınık, 8 Mart 1330, Numru 1, s. 6

Nadir Tevfik, 'İnkılâbın Tarihçesi', Millet, 9 Ağustos 1908, Numru 5, s. 1

Şukufe Nihal Mithat, 'Bugünün Genç Kadınına', Kadınlık, 8 Mart 1330, Numru 1, s. 5 